\title{
An Overview and Evaluation of Highly Porous Adsorbent Materials for Polycyclic Aromatic Hydrocarbons and Phenols Removal from Wastewater
}

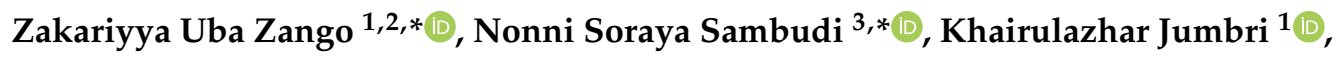 \\ Anita Ramli ${ }^{1}{ }^{\mathbb{D}}$, Noor Hana Hanif Abu Bakar ${ }^{4}$, Bahruddin Saad ${ }^{1}$, \\ Muhammad Nur' Hafiz Rozaini ${ }^{1}$, Hamza Ahmad Isiyaka ${ }^{1}$, Abubaker Mohammed Osman ${ }^{5}$ and \\ Abdelmoneim Sulieman ${ }^{6}$ (D) \\ 1 Fundamental and Applied Sciences Department, Universiti Teknologi PETRONAS, Seri Iskandar 32610, \\ Perak, Malaysia; khairulazhar.jumbri@utp.edu.my (K.J.); anita_ramli@utp.edu.my (A.R.); \\ bahrudsaad@gmail.com (B.S.); Muhammad_18000735@utp.edu.my (M.N.H.R.); \\ hamza_18001996@utp.edu.my (H.A.I.) \\ Chemistry Department, Colllege of Natural and Applied Sciences, Al-Qalam University, 2137 Katsina, Nigeria \\ Chemical Engineering Department, Universiti Teknologi PETRONAS, Seri Iskandar 32610, Perak, Malaysia \\ School of Chemical Sciences, Universiti Sains Malaysia, Pinang 11800, Malaysia; hana_hanif@usm.my \\ Chemistry Department, College of Science, King Khalid University, Abha 62529, Saudi Arabia; \\ abubaker123@gmail.com \\ 6 Radiology and Medical Imaging Department, College of Applied Medical Sciences, Prince Sattam Bin \\ Abduaziz University, Alkharj 16278, Saudi Arabia; a.sulieman@psau.edu.sa \\ * Correspondence: zakariyyazango4@gmail.com (Z.U.Z.); soraya.sambudi@utp.edu.my (N.S.S.); \\ Tel.: +60-174269144 (Z.U.Z.); +60-18957481 (N.S.S.)
}

Received: 15 September 2020; Accepted: 13 October 2020; Published: 19 October 2020

\begin{abstract}
Polycyclic aromatic hydrocarbons (PAHs) and phenolic compounds had been widely recognized as priority organic pollutants in wastewater with toxic effects on both plants and animals. Thus, the remediation of these pollutants has been an active area of research in the field of environmental science and engineering. This review highlighted the advantage of adsorption technology in the removal of PAHs and phenols in wastewater. The literature presented on the applications of various porous carbon materials such as biochar, activated carbon (AC), carbon nanotubes (CNTs), and graphene as potential adsorbents for these pollutants has been critically reviewed and analyzed. Under similar conditions, the use of porous polymers such as Chitosan and molecularly imprinted polymers (MIPs) have been well presented. The high adsorption capacities of advanced porous materials such as mesoporous silica and metal-organic frameworks have been considered and evaluated. The preference of these materials, higher adsorption efficiencies, mechanism of adsorptions, and possible challenges have been discussed. Recommendations have been proposed for commercialization, pilot, and industrial-scale applications of the studied adsorbents towards persistent organic pollutants (POPs) removal from wastewater.
\end{abstract}

Keywords: adsorption; phenols; polycyclic aromatic hydrocarbons; wastewater

\section{Introduction}

Organic pollutants, such as polycyclic aromatic hydrocarbons (PAHs), phenols, and their derivatives, are one of the major pollutants that are frequently detected in wastewater. They are usually originated from both natural and anthropogenic sources, such as bush-burning, volcanic eruptions, petroleum exploration and refining, mining etc. [1,2]. They are usually run-off into the water bodies where 
they reside in the ground and surface water, thus resulting into environmental problem for decades. They are highly lipophilic, semi volatile, and accumulative in water and can be transported into various water compartments due to their non-biodegradable and persistent nature $[3,4]$. They are categorized as persistent organic pollutants (POP's) in the water. When present in the living cells, they are capable of undergoing bioaccumulating and biomagnifying through food webs into different trophic levels of organisms, and subsequently into humans [5].

PAHs are organic compounds consisting of two or more fused benzene ring molecules. They mostly result from petroleum refining, fuel combustion, coal mining and processing, coke production, oil shale pyrolysis, chemicals production, and other industrial processes. Various research conducted in different parts of the world have shown considerable increase in the PAHs concentrations in the receiving water bodies. Thus, PAHs could be ubiquitously transported into the rivers [6,7], fresh and terrestrial water [8], municipal wastewater treatment plants [9], and consequently exposed to the human being and aquatic organism. They are classified based on the number of rings they contained into low molecular weight (LMW-PAHs) and higher molecular weight (HMW-PAHs). The former comprised those PAHs with two to three benzene rings, while the latter are made of four to six rings. In comparisons, the latter are more toxic and persistent to the water due to their low solubility $[10,11]$. The United States Protection Agency (USEPA) has listed 16 PAHs as potential toxic and carcinogenic and thus they have priority concerned. The structures, molecular weight, and $\log p$ values of the PAHs are highlighted in Table 1 .

Table 1. Chemical structures and $\log p$ values of polycyclic aromatic hydrocarbons (PAHs).

\begin{tabular}{|c|c|c|c|c|c|}
\hline Compound & Formula & Abbreviation & Structure & $\begin{array}{c}\text { Molecular } \\
\text { Weight } \\
\text { (g/mol) }\end{array}$ & $\begin{array}{l}\text { Partition } \\
\text { Coefficient }\end{array}$ \\
\hline Naphthalene & $\mathrm{C}_{10} \mathrm{H}_{8}$ & NAP & & 128.17 & 3.37 \\
\hline Acenaphthylene & $\mathrm{C}_{12} \mathrm{H}_{8}$ & $\mathrm{ACE}$ & & 152.1 & 4.0 \\
\hline Acenaphthene & $\mathrm{C}_{1} \mathrm{H}_{10}$ & $\mathrm{ACE}$ & & 154.21 & 3.92 \\
\hline Fluorene & $\mathrm{C}_{13} \mathrm{H}_{10}$ & FLU & & 166.22 & 4.18 \\
\hline Phenanthrene & $\mathrm{C}_{14} \mathrm{H}_{10}$ & PHE & & 178.23 & 4.57 \\
\hline Anthracene & $\mathrm{C}_{14} \mathrm{H}_{10}$ & ANT & & 178.23 & 4.54 \\
\hline
\end{tabular}


Table 1. Cont.

\begin{tabular}{|c|c|c|c|c|c|}
\hline Compound & Formula & Abbreviation & Structure & $\begin{array}{l}\text { Molecular } \\
\text { Weight } \\
\text { (g/mol) }\end{array}$ & $\begin{array}{c}\text { Partition } \\
\text { Coefficient }\end{array}$ \\
\hline Fluoranthene & $\mathrm{C}_{16} \mathrm{H}_{10}$ & FL & & 202.25 & 4.58 \\
\hline Pyrene & $\mathrm{C}_{16} \mathrm{H}_{10}$ & PYR & & 202.25 & 4.58 \\
\hline Benz[a]anthracene & $\mathrm{C}_{18} \mathrm{H}_{12}$ & B[a]A & & 228.3 & 6.14 \\
\hline Chrysene & $\mathrm{C}_{18} \mathrm{H}_{12}$ & CRY & & 228.29 & 5.30 \\
\hline Benzo[b]fluoranthene & $\mathrm{C}_{20} \mathrm{H}_{12}$ & $\mathrm{BbF}$ & & 252.3 & 5.74 \\
\hline Benz[k]fluoranthene & $\mathrm{C}_{20} \mathrm{H}_{12}$ & $\mathrm{BkF}$ & & 252.3 & 5.74 \\
\hline Benz[a]pyrene & $\mathrm{C}_{20} \mathrm{H}_{12}$ & $\mathrm{BaP}$ & & 252.3 & 6.74 \\
\hline Benzo[ghi]perylene & $\mathrm{C}_{22} \mathrm{H}_{12}$ & $\mathrm{BhP}$ & & 276.3 & 6.52 \\
\hline Dibenz[a,h]anthracene & $\mathrm{C}_{22} \mathrm{H}_{14}$ & DahA & & 278.4 & 6.20 \\
\hline Indeno[1,2,3-c,d]pyrene & $\mathrm{C}_{22} \mathrm{H}_{12}$ & IP & & 276.3 & 6.20 \\
\hline
\end{tabular}

Phenols are a class of organic compounds having hydroxyl group $(-\mathrm{OH})$ attached to the carbon atom that is part of the aromatic ring. They have found numerous applications as intermediates for industrial production of petrochemicals, dyes, herbicides, pesticides, pharmaceuticals and cosmetics, etc. [12]. Apart from that, they are also used in household products such as flavorings, cleaners and mouthwash. Thus, they are usually discharged in the wastewater and effluents from those industries $[13,14]$. Even though small quantity of phenols are produced from the decomposition of plants and animals, but anthropogenic sources has been a major contributor of phenols in the environment wastewater effluents in high concentration up to even several thousands of $\mathrm{mg} / \mathrm{L}[15,16]$. Considering their adverse 
effect to living organisms in the environment, they are also classified as priority pollutants [17,18]. The frequent discharge of phenolics without treatment leads to environmental toxicities to the extent that they are posing serious threats to human health. Some of their toxic effects includes; skin and eyes irritations, respiratory complications, weight loss, diarrhea, vertigo, salivation, and dark coloration of urine etc. $[19,20]$. Table 2 presents some of the most frequently reported phenols and their dissociation constants (PKa).

Table 2. Chemical structures and $\log p$ values of polycyclic aromatic hydrocarbons studied.

\begin{tabular}{|c|c|c|c|c|}
\hline Compound & Formula & Structure & $\begin{array}{c}\text { Molecular } \\
\text { Weight } \\
\text { (g/mol) }\end{array}$ & $\begin{array}{c}\text { Partition } \\
\text { Coefficient }\end{array}$ \\
\hline Phenol & $\mathrm{C}_{6} \mathrm{H}_{6} \mathrm{O}$ & & 94.11 & 10.0 \\
\hline Cresol & $\mathrm{C}_{7} \mathrm{H}_{8} \mathrm{O}$ & & 108.14 & 10.28 \\
\hline Resorcinol & $\mathrm{C}_{6} \mathrm{H}_{6} \mathrm{O}_{2}$ & & 110.1 & 19.15 \\
\hline Hydroquinone & $\mathrm{C}_{6} \mathrm{H}_{6} \mathrm{O}_{2}$ & & 110.11 & 9.9 \\
\hline Pyrogallol & $\mathrm{C}_{6} \mathrm{H}_{6} \mathrm{O}_{3}$ & & 126.11 & 9.03 \\
\hline Naphthol & $\mathrm{C}_{6} \mathrm{H}_{8} \mathrm{O}$ & & 144.17 & 9.51 \\
\hline Salicylic acid & $\mathrm{C}_{7} \mathrm{H}_{6} \mathrm{O}_{3}$ & & 178.23 & 2.97 \\
\hline
\end{tabular}


Table 2. Cont.

Compound $\quad$ Formula

In recognition of the mobilities and high toxicities of these pollutants in environmental waters, a prompt response from various environmental monitoring and protection is needed to reduce their concentrations, or to ideally completely eliminate them. Thus, considerable attention has been paid to develop suitable techniques for their effective remediation [21,22]. Over the last three decades, extensive studies have been conducted using different technologies including coagulation and flocculation, phytoremediation, reverse and forward osmosis, chemical oxidation, photocatalytic degradation and adsorption [23-25]. Table 3 highlights the pros and cons of some of the remediation techniques employed. Generally, most of these techniques failed to address the persistent problem, partly because the pollutants are highly lipophilic. In a conventional wastewater treatment plant (WWTPs), they are resistant to bioremediation and photolysis is insignificant for their degradations [26]. Additionally, the excessive chemical remediation might cause secondary pollution because of the unreasonable proportions of the reagents used and formation of oxygenated species that are potentially hazardous $[27,28]$. Photocatalytic degradation has been limited by the semi conducting property of the materials and the utilization of light energy. Additionally, most of the techniques are non-feasible and non-economical. 
Table 3. Pros and Cons of Wastewater treatments process used for PAHs and phenols remediation.

\begin{tabular}{|c|c|c|}
\hline Method & Pros & Cons \\
\hline Coagulation & $\begin{array}{l}\text { - The colloidal particles are easily settled down by } \\
\text { the coagulants added to the wastewater }\end{array}$ & $\begin{array}{ll}\text { - } & \text { It is time-consuming } \\
\text { - } & \text { Incomplete removal of the organic pollutants are } \\
\text { always the case } \\
\text { - } \quad \text { It resulted in secondary pollution inform of sludge }\end{array}$ \\
\hline Flocculation & $\begin{array}{l}\text { - Availability of various flocculants that have } \\
\text { been commercialized. } \\
\text { - Some of the flocculants have shown a high affinity } \\
\text { to the organic pollutants. }\end{array}$ & $\begin{array}{l}\text { - It is highly dependent on the physicochemical } \\
\text { parameters of the pollutants; such as } \mathrm{pH} \text { and } \\
\text { ionic strength. } \\
\text { - The flocculants often resulted } \\
\text { in secondary pollution. }\end{array}$ \\
\hline $\begin{array}{l}\text { Bioremediation; including the use of microbes such as } \\
\text { bacteria, fungi, and algae. }\end{array}$ & $\begin{array}{l}\text { - It was employed for the treatments of PAHs } \\
\text { at the contamination site and wastewater } \\
\text { treatment plants } \\
\text { - Availability and low-cost of various microbes. } \\
\text { - It is a simple process }\end{array}$ & $\begin{array}{l}\text { - } \quad \text { The method requires nutrients for the microbes } \\
\text { to flourish. } \\
\text { - Temperature optimization for the condition has } \\
\text { been a challenge. } \\
\text { - A long time is required to degrade } \\
\text { organic pollutants. }\end{array}$ \\
\hline Reverse Osmosis & $\begin{array}{l}\text { - No chemicals are added to the pollutants; hence } \\
\text { no secondary pollutants are generated. } \\
\text { - It is available for large scale application using } \\
\text { sophisticated reverse osmosis membranes systems }\end{array}$ & $\begin{array}{l}\text { - It is costly, especially for small and } \\
\text { medium-scale applications. } \\
\text { _ } \quad \text { It is a time-consuming process. }\end{array}$ \\
\hline Chemical oxidations & $\begin{array}{l}\text { - The organic pollutants such as PAHs and phenols } \\
\text { are easily oxidized to carbon dioxide and water. } \\
\text { - No sludge is generated in the process; thus, it is } \\
\text { environmentally friendly. }\end{array}$ & $\begin{array}{l}\text { - The high cost of operation and maintenance } \\
\text { - Since it involved the use of hydrogen peroxide, } \\
\text { it may result in harmful effects to humans if not } \\
\text { considerably removed. }\end{array}$ \\
\hline
\end{tabular}


Table 3. Cont.

\begin{tabular}{|c|c|c|}
\hline Method & Pros & Cons \\
\hline Solvent extraction and ion exchange process & $\begin{array}{l}\text { - It is a rapid process with high efficiency for the } \\
\text { removal of PAHs and phenols in wastewater. } \\
\text { - The cost of operation is cheap } \\
\text { - The extractants are mostly reusable, thus, } \\
\text { it is economical. }\end{array}$ & $\begin{array}{l}\text { - } \quad \text { Some solvents are toxic; thus, cross-contamination } \\
\text { may occur. } \\
\text { - The use of volatile solvents may result } \\
\text { in fire emission. } \\
\text { - Not suitable at the low concentration } \\
\text { of the pollutants. }\end{array}$ \\
\hline Photocatalytic degradation & $\begin{array}{l}\text { - Complete mineralization of the pollutants to } \\
\text { carbon dioxide and water } \\
\text { - The photocatalysts are upon reusable from the } \\
\text { economic point of view. } \\
\text { - } \quad \text { It is an environmentally friendly technique. } \\
\text { - It is mostly operated under room temperature. }\end{array}$ & $\begin{array}{l}\text { - A sufficient light source of energy is required to } \\
\text { excite the photocatalyst. } \\
\text { - } \quad \text { Some of the photocatalysts are expensive, thus not } \\
\text { economical for industrial-scale applications. } \\
\text { - The photocatalytic reactor is expensive for } \\
\text { both purchasing and maintenance. }\end{array}$ \\
\hline Adsorption process & $\begin{array}{l}\text { _ } \quad \text { It is simple to design and operate. } \\
\text { - } \quad \text { Availability of various forms of locally synthetic } \\
\text { adsorbents materials. } \\
\text { - Low-cost adsorbents and commercial adsorbents } \\
\text { are available. } \\
\text { - Complete adsorption of the pollutants can be } \\
\text { achieved within a short time. } \\
\text { - It is an environmentally friendly technique. } \\
\text { - } \quad \text { Reusability of the adsorbents. }\end{array}$ & $\begin{array}{l}\text { - Adsorbent regeneration is often difficult } \\
\text { and costly. } \\
\text { - } \quad \text { A high temperature is needed to dissolve high } \\
\text { molecular weight pollutants. } \\
\text { - Spent adsorbent may be considered hazardous } \\
\text { but are usually incinerated. }\end{array}$ \\
\hline
\end{tabular}


However, adsorption has been recognized as the major technique for the effective removal due to the high affinity the various adsorbents for the organic pollutants. Additionally, the process has been recognized for its simplicity, low-cost, availability of various adsorbents materials, non-environmental toxicity, ease of design, etc. Figure 1 presents the literature survey conducted via web of science and for publications reported and patents for various remediation for PAHs and phenols. The prominence of adsorption is clearly seen among the techniques. It is thus justifiable that this review was conducted for the removal of PAHs and phenols using adsorption techniques. Critical analysis was conducted using various advanced porous adsorbents and the adsorptive performance of the materials have been highlighted. To some extent, the mechanism for the adsorptions have been discussed.

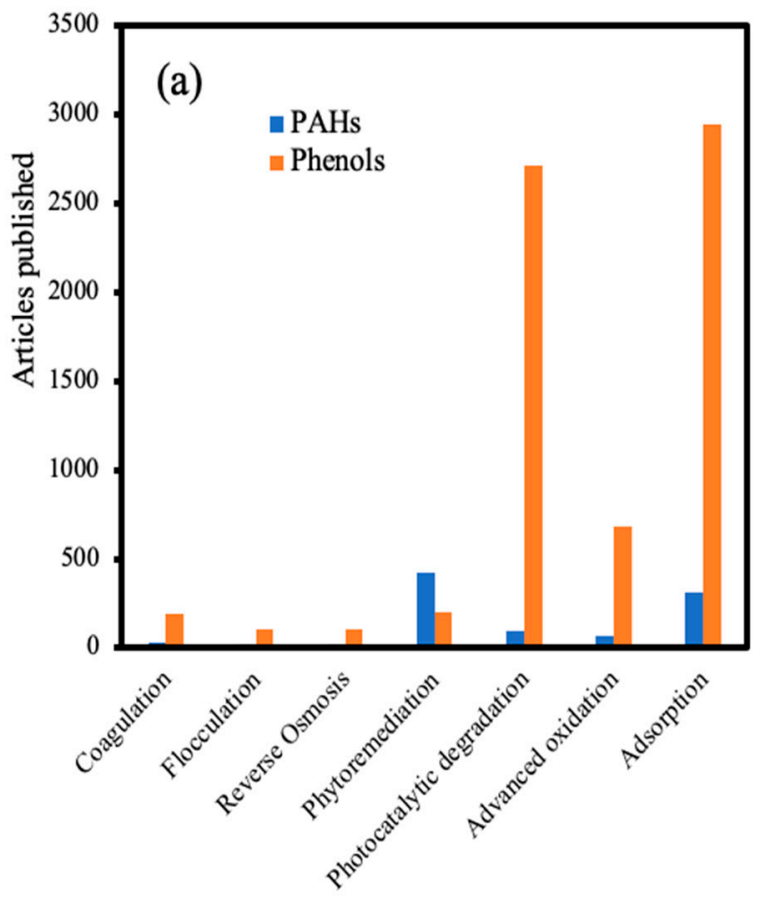

Treatment processes

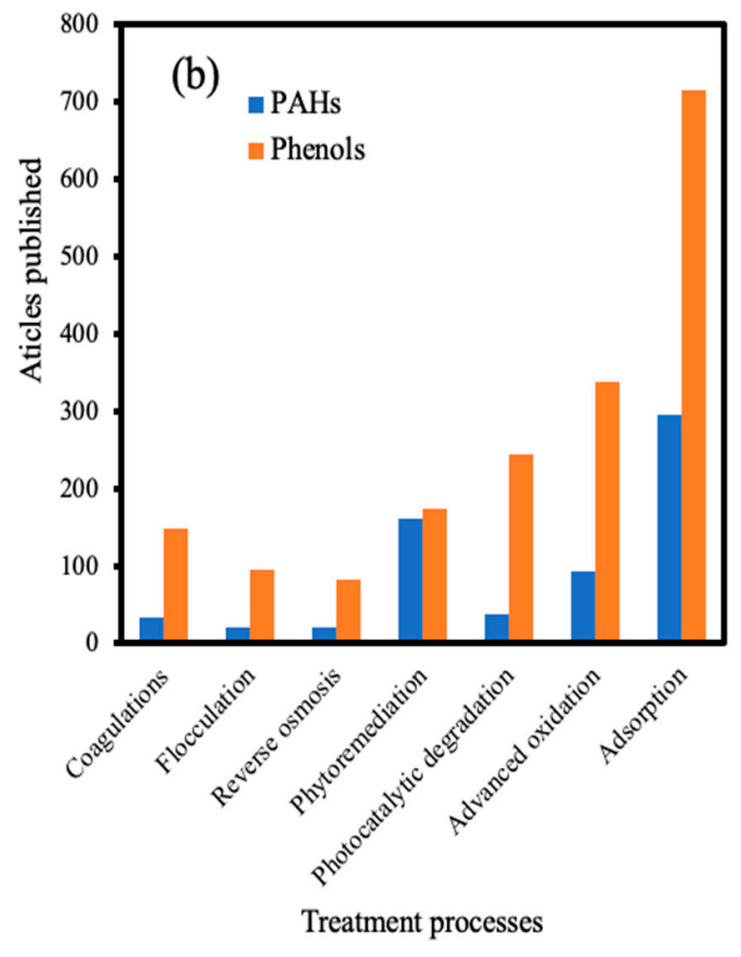

Treatment processes

Figure 1. Trends of (a) publications and (b) patents on various treatment techniques for PAHs and phenols remediation: Data obtained from the web of science using keywords: Adsorptions, Advanced oxidation, Coagulation, Flocculation, PAHs, Phenols, Phytoremediation, Photocatalytic degradation, Reverse osmosis.

\subsection{Sources of PAHs and Phenols}

Industrial activities driving by energy and power demands have been the major source of PAHs and phenolic compounds in the environment. In particular, the refining of crude oil is usually associated with the production of various by-products such as petrol, diesel, coal tar, etc. [29]. Crude and refined oil leakage have also been widely recognized as one of the major sources of PAHs and phenols in the water [30]. It has been estimated, around 5-30 million tons of crude oil spilt into the ocean every year [31], as a result of either accident or leakage oil tankers. One of the most recent ones is the oil spill which occurred in Ambarnaya river and Mauritius coast in May and July 2020, respectively. In both cases, the spills were reported to occupy large area and consequently washed into the oceans. Petroleum and industrial sludges have also been a major deposit of PAHs and phenols [32,33].

Apart from petroleum and petrochemicals, coal processing to generate heat and power, as well as coke production, has also been identified as another way through which PAHs and phenolic compounds get into the water [34]. The generation of electricity from coal has been widely practiced, taking about one third of the total electricity generation [35]. According to the Environmental Protection Agency, coal fire plants contributed to about a third of the total global water pollution due to the various toxic 
chemicals such as PAHs, phenolic compound, and heavy metals discharged into the rivers, streams, and other water bodies [36]. Thus, the concentrations of these pollutants in the coal wastewater is high when discharged into the atmosphere and are said to be contributing to the persistent problem of global warming [37].

PAHs and phenols have been identified as one of the major contaminants in wastewater, ans usually exist in complex. The textile and dyeing industry have been a major contributor to PAHs. According to the China environmental statistics yearbook of 2012, discharge of wastewater from dyeing industries was about 2.37 billion. Accordingly, Ning et al., (2014), reported that the total number of 16 different PAHs with concentration range of $1463-16,714 \mathrm{ng} / \mathrm{g}$ has been detected in textile dyeing sludge from Guangdong [38]. Natural and anthropogenic sources of phenols have been discussed by Anku et al., (2016), highlighting the contribution of dissolved organic matter in increasing the phenols concentrations in the environment [39]. Floodwater is another source of which PAHs and phenolic compounds get into wastewater. The catastrophe of flooding has been a common phenomenon in different places of the world, particularly in the tropical areas, where rainfall is very high over a long period of the year [40]. For example, Chukwujindu et al. (2017) reported on the prevalent occurrences of flood along the River Niger and River Benue in Nigeria, as a result of excessive rainfall during the wet season [41]. Even though no established finding between the magnitude and frequency of a flood event has been found (especially large floods), the resulting environmental changes has been reported. However, Ciesielczuk et al. (2014) described that PAHs and phenols are usually adsorbed on the humic acids in the floodwaters and thus migrated to the water [42].

\subsection{PAHs and Phenols in Wastewater Treatment Plants (WWTPs)}

WWTPs has been the secondary source of PAHs and phenols. WWTPs serve as the major reservoir of wastewater collected from a wide range of domestic and industrial sources. Thus, various pollutants from these sources have been found to concentrate along with the solid particles in the wastewater [25]. According to the J. Liu et al. (2011), PAHs were detected in domestic WWTP in Xian, China for a period of one year, originated from domestic usage of petrochemical substances such as oil and grease, cosmetics, etc. Therefore, WWTPs is acting as the secondary source of PAHs from the different sources [43].

\subsection{Toxicities of PAHs and Phenols to Humans}

Much attention has been given to the study of toxicities of PAHs and phenols to humans. The source of human exposure has been mostly linked to consumption of contaminated water, air inhalation or from infected foods $[44,45]$. The exposure is more pronounced to communities living at the site of petroleum exploration and refining or near the coastal areas where discharged wastewater is released into rivers, oceans or seas [46]. Industrial water has higher risk of contaminations than the municipal WWTPs as in the former, the wastewater is directly coming from the source such as coke production plants which contains mixture of complex compounds such as PAHs, phenols and nitrogen containing aromatics [47].

The level of bioaccumulation of PAHs in humans is determined by the toxicities which increased with molecular weight. Long term exposure usually resulted in acute toxicities, associated with carcinogenicity and mutagenicity [48]. High exposure increased the risk of cancer of various organs such as lung, breast, prostate, kidney, bladder, stomach, and skin [26]. They are also reported to suppress the immune of the body, thus they are labeled as endocrine disruptors [49]. Chukwujindu et al. (2017), studied the effect of exposure to PAHs due to overflooding of PAH contaminated water with the associated health risk. They employed the technique of incremental lifetime cancer risk (ILCR) to determine the extent of the PAHs exposure among various age groups in the study area. The finding shows that on the average, the total ILCR values obtained in 2014 were 443 and 308 chances in a million among the children and adults, respectively, and that the number of the risk of cancer was 6450 and 4480 chances for children and adults, respectively, about a 15-fold decrease in the average total 
ILCR values. Thus, they estimated high risk of exposure among adults than children, attributed to the prolong duration of exposure for the adults [41].

On the other hand, phenols are potential human carcinogens. They are found to exert toxic effects even at lower concentrations. At higher concentrations, phenols has the tendency to coagulate with the proteins in the body, which may result in cellular and cytoplasmic permeability, hence, could cause damage of the sensitive cells, cardiovascular, and central nervous system [50]. Prolonged ingestion of phenols may result into mouth sore, dark urine, and even diarrhea [51].

\subsection{Environmental Regulations on PAHs and Phenols}

In an effort to eliminate the effect of PAH and other toxic chemicals into the environmental waters, the United Nation has set the regulation to stop the establishment of coal power plants around the globe to tackle the climate change and water pollution challenges [47,52]. The United States Protection Agency (USEPA) has categorized 16 PAHs as priority pollutants of carcinogenic and mutagenic effect in water [25]. To limit the PAHs and other toxic contaminants from the environmental water, E.U has regulations to forbid sludge disposal. The Ministry of Environmental Protection of China has set the level of toxic PAHs and B[a]PYR in wastewater treatment plant as $50 \mu \mathrm{g} / \mathrm{L}$ and $0.03 \mu \mathrm{g} / \mathrm{L}[2,9]$ respectively.

Phenol has been detected in various water samples ranging from hazardous waste sites, surface water, rainwater, ground water, sediments, industrial and urban runoff, as well as the drinking water. The level of toxicity of phenol in human and aquatic animals has been identified as 9-25 mg/L [53]. Considering the toxicity and environmental impact of phenolic compounds in water, the USEPA has included them under the listed of priority pollutants with limited environmental discharge of less than $1 \mathrm{mg} / \mathrm{L}$ in the treated effluents and set their maximum content in potable water as $0.5 \mathrm{mg} / \mathrm{L}$ [54]. Similarly, the World Health Organization (WHO) has regulated the concentration of phenol in potable drinking water at $0.001 \mathrm{mg} / \mathrm{L}$ [55].

\section{PAHs and Phenols Remediation in Wastewater}

Considering the negative impact of PAHs and phenols with their derivatives in wastewater, various forms of remediation have been proposed. Some of these techniques reported includes conventional methods such as coagulation, flocculation, activated sludge, and bioremediation $[42,56]$. Other techniques such as membrane technology, photocatalytic degradation, advanced oxidation, and electrochemical catalysis have also been reviewed $[57,58]$. Some of these techniques have shown considerable promise [26], while some are facing challenges of incomplete removal or degradation of the pollutants, generations of other toxic contaminants [24,59], complexity of the method, as well as the cost of application and maintenance. Hence, the quest for more alternative techniques has seemed endless.

Adsorption techniques using various adsorbent materials from natural and synthetic origins have been well studied due to their prospects to effectively removed the pollutants from water. These technique are simple, economical, and practicable [60]. The ease of operation and non-generation of secondary pollutants are other advantages enjoyed by the method.

\subsection{PAHs and Phenols Removal by Adsorption}

In the adsorption process, pollutants in the solution are trapped on the surface of suspended particles, known as the adsorbent materials. Adsorption technology is motivated by the availability of a broad spectrum of low-cost adsorbents obtained from abundant naturally occurring and waste substances such as mineral deposits, agricultural waste products, particulate organic matters, and solid industrial wastes [61]. Thus, it provides an alternative for transforming waste materials into useful material for environmental sustainability.

Apart from the naturally occurring materials, synthesized particles with higher surface area and pore volumes such as organic and inorganic polymers, porous carbon materials, graphene, silica-based 
materials, have been successfully utilized as adsorbents for the PAHs and phenols removal from the wastewater [62,63]. Adsorption process is usually carried out in a batch reactor on a small scale, non-continuous process such as in research laboratories [64], or using a more advanced technique of fixed bed reactors or column for a pilot-scale industrial and water treatment plants application [65]. Villegas et al. (2016) [53] discussed on various methods for phenols removal in wastewater, however, emphasis was laid mainly on activated carbon $(A C)$, those other highly porous adsorbents such as silica and metal-organic frameworks (MOFs) have not been considered.

In this article, we aimed at reviewing and discussing past and present scenario of using various adsorbent materials for the removal of PAHs and phenols from water. The review also provides scientific analysis and propose future research directions on the use of promising adsorbent materials for PAHs and phenols adsorptive removals in the water.

\subsection{Adsorption of PAHs and Phenols onto Porous Carbon Materials}

The use of porous carbon materials as adsorbents for organic pollutants removal from aquatic environment was first mentioned by Walters and Luthy (1984) [66]. They argued that porous carbon adsorbents are superior to soils, sediments, and suspended organic matters in terms of removal of PAHs. This claim has catalyzed discoveries of various porous carbon materials for wastewater remediation. The use of porous carbon materials such as activated carbon (AC) prepared from various agricultural waste materials [67,68], biochar [69,70], carbon nanotubes (CNTs) [71,72], and other derived carbon materials for the adsorption of PAHs have been studied.

\subsubsection{Biochar}

Biochar is a carbonaceous solid obtained from waste materials such as agricultural wastes, sewage sludge (SSL), and petroleum sludge (PS). For example, sewage sludge is generated as a by-product of sewage treatment. It is composed of many organic and inorganic substances as well as hazardous biological materials [73,74]. Thus, these solid wastes are harmful to the environment and requires proper disposal. Interestingly, pyrolysis is used as an alternative thermochemical technique to convert the waste sludge into useful biochar for effective industrial and environmental applications. It has been identified as one of the major forms of porous derived carbon. Godlewsky et al. (2019) investigated the effect of atmosphere nitrogen $\left(\mathrm{N}_{2}\right)$ and carbon dioxide $\left(\mathrm{CO}_{2}\right)$ for the production of sludge derived-biochar under pyrolysis temperatures of $500-700{ }^{\circ} \mathrm{C}$. The use of $\mathrm{CO}_{2}$ atmosphere was able to generate biochar with improved properties such as higher BET surface area, porosity as compared to those obtained under $\mathrm{N}_{2}$ atmosphere [56].

Biochar that are derived from biomass-derived is by far the most important means to produce the porous carbon materials. It has been estimated that, the world production of dry biomass is about 220 billion tons annually [75], thus pyrolysis treatment to energy and biochar is interesting option [76,77]. Agricultural waste materials such as rice husk [78], wheat straw [79], and palm kernel seeds [80] have been reportedly used for PAHs and phenol adsorption in water.

The review by Bedia et al. (2018) focused mainly on the use of biomass derived biochar for emerging contaminants adsorptions in water streams [81]. In comparison to sludge derived-biochar, biomass derived-biochar has been found to possess higher specific surface area and pore volumes which was attributed to the higher carbon content in the latter [77]. Thus, high removal of PAHs (pyrene and benzo[a]pyrene) has been reported by Qiao et al. (2018) using biomass derived biochar generated from Enteromorpha prolifera at $200^{\circ} \mathrm{C}$. The Langmuir monolayer maximum adsorption capacities were estimated to be $187.27 \mu \mathrm{g} / \mathrm{g}$ and $80.00 \mu \mathrm{g} / \mathrm{g}$, for the pyrene and benzo[a]pyrene, respectively [82]. Recently, Arshad et al. (2019) reported on response surface method (RSM) optimizations of phenol adsorption onto oil-palm bunch derived biochar [80]. Lee et al. (2019) reported on the effective removal of phenol using biochar generated from food waste Factors that affect the adsorption of PAHs and phenols onto biochar include pore size and volume of the adsorbent as well as the concentration of the pollutants [20]. The review by Lamichhane et al., 2016 [25] also highlighted some advantages 
of biochar in the removal of PAHs. Different biochars for the adsorptions of PAHs and phenols in water streams are summarized in Table 4.

Table 4. Adsorptions of PAHs and phenols using biochars.

\begin{tabular}{|c|c|c|c|c|c|}
\hline Adsorbent & Pollutant & $\begin{array}{c}\text { Concentration } \\
(\mathrm{mg} / \mathrm{L})\end{array}$ & $\begin{array}{c}\mathrm{Q}_{\mathrm{e}} \\
(\mathrm{mg} / \mathrm{g})\end{array}$ & $\begin{array}{l}\text { Equilibrium } \\
\text { Time }\end{array}$ & Ref \\
\hline $\begin{array}{c}\text { RHB } \\
\text { Magnetic modified RHB }\end{array}$ & PHE & 5 & $\begin{array}{l}17 \\
42\end{array}$ & $1 \mathrm{~h}$ & [78] \\
\hline $\begin{array}{l}\text { Biochar } \\
\text { graphene/biochar composite }\end{array}$ & PHE & 1 & $\begin{array}{l}2 \\
3\end{array}$ & 3 days & [83] \\
\hline Rice-350-M & $\begin{array}{l}\mathrm{PHE} \\
\mathrm{BaA}\end{array}$ & 1 & $\begin{array}{l}43 \\
19\end{array}$ & $24 \mathrm{~h}$ & [69] \\
\hline Elephant grass biochar & $\begin{array}{c}\text { BkF } \\
\text { BaP } \\
\text { DahA }\end{array}$ & 0.1 & $\begin{array}{c}19 \\
18 \\
8\end{array}$ & $250 \mathrm{~min}$ & [84] \\
\hline Poplar Catkins biochar & PHE & 30 & 384 & $1120 \mathrm{~min}$ & [85] \\
\hline Sewage sludge char & $\begin{array}{l}\text { PHE } \\
\text { PYR }\end{array}$ & 0.8 & - & $24 \mathrm{~h}$ & [56] \\
\hline Wood biochar & $\begin{array}{l}\text { PYR } \\
\text { PHE }\end{array}$ & 9.1 & - & & \\
\hline Wheat straw biochar & $\begin{array}{l}\text { FLU } \\
\text { PYR }\end{array}$ & $\begin{array}{c}10.0 \\
11\end{array}$ & $\begin{array}{l}- \\
-\end{array}$ & $48 \mathrm{~h}$ & [79] \\
\hline Chitin biochar & $\begin{array}{c}\text { phenol } \\
\text { 2-nitrphenol }\end{array}$ & 500 & $\begin{array}{l}184 \\
206\end{array}$ & $12 \mathrm{~h}$ & \\
\hline Hizikia fusiformis biochar & phenol & 50 & 30 & $1440 \mathrm{~min}$ & [86] \\
\hline $\begin{array}{l}\text { Black spruce biochar } \\
\text { White birch biochar }\end{array}$ & phenol & 200 & $\begin{array}{l}233 \\
150\end{array}$ & $\begin{array}{c}18 \mathrm{~h} \\
4 \mathrm{~h}\end{array}$ & [87] \\
\hline Chinese herb biochar & phenol & 50 & - & $360 \mathrm{~min}$ & [88] \\
\hline $\begin{array}{l}\text { scots pine bark biochar } \\
\text { spruce bark biochar }\end{array}$ & phenol & 500 & $\begin{array}{c}149 \\
84\end{array}$ & $24 \mathrm{~h}$ & [89] \\
\hline $\begin{array}{l}\text { Bamboo biochar } \\
\text { Oak wood biochar }\end{array}$ & phenol & 10 & $\begin{array}{l}17 \\
13\end{array}$ & $24 \mathrm{~h}$ & [90] \\
\hline Food waste biochar & phenol & 10 & 3 & $30 \mathrm{~min}$ & [20] \\
\hline $\begin{array}{l}\text { Japanese red pine char } \\
\text { Yellow poplar char }\end{array}$ & $\begin{array}{l}\text { Phenol } \\
\text { Phenol }\end{array}$ & 200 & $\begin{array}{l}6 \\
7\end{array}$ & $30 \mathrm{~min}$ & [61] \\
\hline Pine fruit shell biochar & Phenol & 50 & 27 & $24 \mathrm{~h}$ & [91] \\
\hline
\end{tabular}

\subsubsection{Activated Carbon (AC)}

AC are highly porous carbon materials obtained from agricultural wastes, with high carbon contents such as cellulose, hemicellulose, lignin, lipids, proteins, simple sugars, and starch [67,92]. The production of AC involved thermal decomposition of these materials under limited supply of air, followed by the activation to generate highly porous carbon material. Thus, precursors for AC are usually low-cost agricultural waste materials such as husk [93], shells [94], wood [95], sawdust [96], rice husk [66], etc. The use of other materials such as bones, cartilages, coke etc. have also been employed [97]. It has been widely employed for a variety of industrial applications such as gas separations and purifications, liquid and gas storage, super capacitors, electrodes, catalysis, and removal of toxic substances in contaminated wastewater etc. [98]. They are usually characterized by a large surface area and large porosity than most of the conventional adsorbents ever reported. However, the properties are largely dependent on the precursor material, pyrolysis temperature, and the activation conditions. In some cases, the AC produced might contain heteroatoms and mineral matter (ash content) depending on the nature of the raw material used as precursor. A literature has shown that over 26,000 articles have been published by Elsevier on the use of AC for the adsorption of pollutants in aqueous medium. Danish and Ahmad 2018, has reviewed on the production of AC from wood biomass as adsorbent materials. Pore size, pore diameter distribution, of AC as the major contributing factor for the adsorption of the pollutants [92]. 
Different forms of AC such as AC powdered activated carbons (PAC) and granular activated carbons (GAC) $[99,100]$ from different biomass has been reportedly used for organic pollutants removal from water (Figure 2). Additionally, the use of modified AC to regulate its pore structure and chemical properties for the effective removal has been studied [101]. Wu et al. (2020) recently reported on the preparation of walnut shell AC (WAC) with a surface area of $438.5 \mathrm{~m}^{2} / \mathrm{g}$ via microwave-assisted $\mathrm{KOH}$ activation process at $900 \mathrm{~W}$ for the competitive adsorption of NAP and PHE in aqueous medium. Equilibrium adsorption of $40 \mathrm{~min}$, with the adsorption capacities of 39.58 and $63.37 \mathrm{mg} / \mathrm{g}$ for the NAP and PHE respectively were obtained [98]. More porous AC were produced via modified coal-base AC (MCAC) and iron-modified coal-base AC (Fe-MCAC) with BET surface area of 1062 and $1079.67 \mathrm{~m}^{2} / \mathrm{g}$ respectively for PAHs adsorption [102]. Similarly, optimizations studies for the phenols adsorption was studied using AC obtained from Terminalia chebula (TCAC). Equilibrium time of $24 \mathrm{~h}$ with the monolayer adsorption capacity of $36.77 \mathrm{mg} / \mathrm{g}$ were observed. Table 5 presented more literature on the application of AC as adsorbent for PAHs and phenols removal.
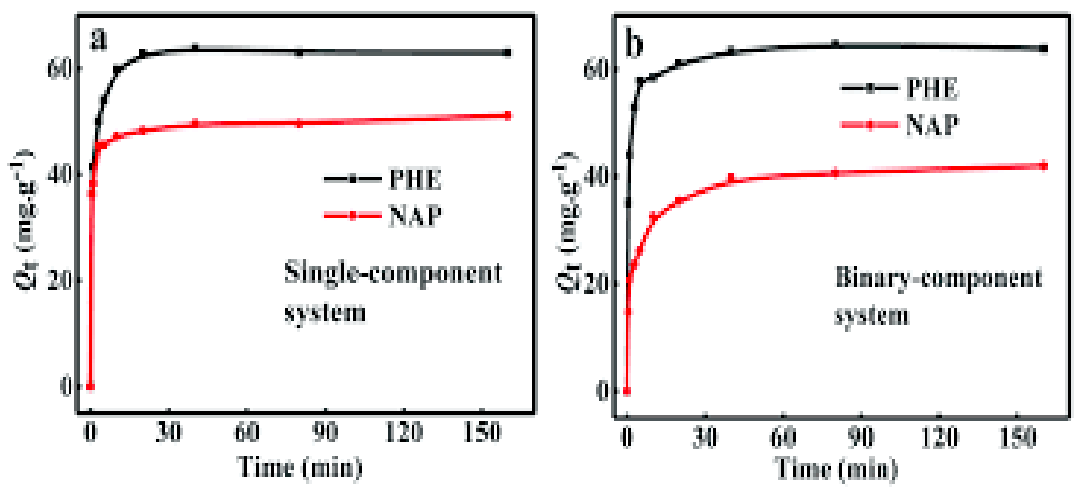

Figure 2. Kinetic studies and adsorption capacities for the removal of NAP and PHE using walnut shell activated carbon (WAC) under (a) single and (b) binary systems [103]. Copyright: Royal Society of Chemistry (2020).

Table 5. Adsorptions of PAHs and phenols using different forms activated carbon (AC).

\begin{tabular}{|c|c|c|c|c|c|}
\hline Adsorbent & Pollutant & $\begin{array}{c}\text { Concentration } \\
(\mathrm{mg} / \mathrm{g})\end{array}$ & $\begin{array}{c}Q_{e} \\
(\mathrm{mg} / \mathrm{g})\end{array}$ & $\begin{array}{l}\text { Equilibrium } \\
\text { Time }\end{array}$ & Ref \\
\hline \multirow{2}{*}{ Commercial PAC } & ANT & \multirow{2}{*}{-} & 143 & $4 \mathrm{~h}, 5 \mathrm{~min}$ & \multirow{2}{*}{ [68] } \\
\hline & PYR & & 142 & $4 \mathrm{~h}, 10 \mathrm{~min}$ & \\
\hline \multirow{3}{*}{ Commercial AC } & PHE & 120 & 46 & \multirow{3}{*}{$24 \mathrm{~h}$} & \multirow{3}{*}[104]{} \\
\hline & FLA & 80 & 36 & & \\
\hline & $\mathrm{BaA}$ & 12 & 9.7 & & \\
\hline \multirow{3}{*}{ Rice husk AC } & NAP & 8 & 14 & \multirow{3}{*}{$24 \mathrm{~h}$} & \multirow{3}{*}{ [66] } \\
\hline & PHE & & 17 & & \\
\hline & PYR & & 18 & & \\
\hline Flamboyant pod back AC & & & 4.7 & \multirow{3}{*}{$2 \mathrm{~h}$} & \multirow{3}{*}{105} \\
\hline \multirow{3}{*}{$\begin{array}{c}\text { Milk bush kernel AC } \\
\text { Rice husk AC }\end{array}$} & $\mathrm{ACE}$ & 50 & 4 & & \\
\hline & & & 5.6 & & \\
\hline & NAP & & 15 & \multirow{3}{*}{$24 \mathrm{~h}$} & \multirow{3}{*}{ [106] } \\
\hline \multirow[t]{2}{*}{ Rice husk AC } & PHE & 8 & 17.5 & & \\
\hline & PYR & & 18 & & \\
\hline \multirow{2}{*}{ Rice husk AC } & PHE & 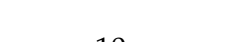 & - & $60 \mathrm{~min}$ & \multirow{2}{*}{ [107] } \\
\hline & FLU & 10 & - & $30 \mathrm{~min}$ & \\
\hline Rice husk AC & $\mathrm{ACE}$ & 50 & 46 & $3 \mathrm{~h}$ & [93] \\
\hline Vitis vinifera leaf $\mathrm{AC}\left(\mathrm{Zncl}_{2}\right)$ & \multirow{2}{*}{ PHE } & \multirow{2}{*}{1} & 94 & \multirow{2}{*}{$180 \mathrm{~min}$} & \multirow{2}{*}{ [108] } \\
\hline Vitis vinifera leaf $\mathrm{AC}\left(\mathrm{H}_{3} \mathrm{PO}_{4}\right)$ & & & 89 & & \\
\hline
\end{tabular}


Table 5. Cont.

\begin{tabular}{|c|c|c|c|c|c|}
\hline Adsorbent & Pollutant & $\begin{array}{c}\text { Concentration } \\
(\mathrm{mg} / \mathrm{g})\end{array}$ & $\begin{array}{c}\mathrm{Q}_{\mathrm{e}} \\
(\mathrm{mg} / \mathrm{g})\end{array}$ & $\begin{array}{l}\text { Equilibrium } \\
\text { Time }\end{array}$ & Ref \\
\hline \multirow{2}{*}{ Walnut shell AC } & NAP & 10 & 49.6 & \multirow{2}{*}{$40 \mathrm{~min}$} & \multirow{2}{*}{ [103] } \\
\hline & PHE & 10 & 63.8 & & \\
\hline \multirow[t]{2}{*}{$\begin{array}{l}\text { flamboyant pod AC } \\
\text { milk bush kernel shell AC }\end{array}$} & NAP & 50 & $\begin{array}{c}294.2 \\
63.3\end{array}$ & \multirow[t]{2}{*}{$2 \mathrm{~h}$} & \multirow[t]{2}{*}{ [94] } \\
\hline & NAP & & 78.2 & & \\
\hline \multirow[t]{3}{*}{ Coal-based AC } & PHE & 200 & 111.4 & \multirow[t]{3}{*}{$20 \mathrm{~min}$} & \multirow[t]{3}{*}{ [98] } \\
\hline & PYR & & 117.2 & & \\
\hline & NAP & & 167.8 & & \\
\hline \multirow[t]{2}{*}{ Fe-modified Coal-based AC } & PHE & 30 & 190.4 & \multirow[t]{2}{*}{$40 \mathrm{~min}$} & \multirow[t]{2}{*}{ [101] } \\
\hline & PYR & & 20.3 & & \\
\hline Terminalia chebula AC & phenol & 100 & 26.2 & $24 \mathrm{~h}$ & [109] \\
\hline Commercial AC & phenol & 1000 & 132.3 & $360 \mathrm{~min}$ & [110] \\
\hline Commercial AC & & \multirow{3}{*}{100} & & & \\
\hline Miswak root $\mathrm{AC}$ & \multirow[t]{2}{*}{ phenol } & & 142.2 & \multirow[t]{2}{*}{$120 \mathrm{~min}$} & \multirow[t]{2}{*}{ [111] } \\
\hline Coal-based GAC & & & 169.9 & & \\
\hline Coal-based PAC & \multirow[t]{2}{*}{ phenol } & \multirow[t]{2}{*}{300} & 176.6 & \multirow[t]{2}{*}{$180 \mathrm{~min}$} & \multirow[t]{2}{*}{ [112] } \\
\hline Coconut shell PAC & & & 213 & & \\
\hline Cherry stone AC & \multirow[t]{2}{*}{ phenol } & \multirow[t]{2}{*}{25} & 80 & \multirow[t]{2}{*}{$24 \mathrm{~h}$} & \multirow[t]{2}{*}{ [113] } \\
\hline Agave Utahensis AC & & & 1.7 & & \\
\hline Euphorbia Resinifira AC & \multirow[t]{2}{*}{ Phenol } & \multirow[t]{2}{*}{14} & 1.9 & \multirow[t]{2}{*}{$3 h$} & [114] \\
\hline Banana peel AC & & & 2.0 & & \\
\hline Oily sludge AC & phenol & 100 & 434 & $30 \mathrm{~min}$ & [115] \\
\hline Tea waste AC & phenol & 100 & 132.5 & $4 \mathrm{~h}$ & [67] \\
\hline Babul sawdust AC & phenol & 50 & 15.3 & $60 \mathrm{~min}$ & [96] \\
\hline Olive stone AC & phenol & 800 & 44,269 & $4 \mathrm{~h}$ & [116] \\
\hline Palm oil bunch AC & phenol & 40 & 55.3 & $2 \mathrm{~h}$ & [117] \\
\hline Wood fiberboard AC & phenol & 250 & 208 & $120 \mathrm{~min}$ & [95] \\
\hline Avocado kernel AC & phenol & 0.7 & 3.3 & $100 \mathrm{~min}$ & [118] \\
\hline Date pit AC & Phenol & 50 & 46 & $1 \mathrm{~h}$ & [119] \\
\hline Sugar cane bagasse AC & Phenol & 100 & 27 & $30 \mathrm{~min}$ & [120] \\
\hline Lantana camara AC & Phenol & 150 & 112.5 & $7 \mathrm{~h}$ & [121] \\
\hline Magnetic AC & phenol & 80 & 107.5 & $15 \mathrm{~min}$ & [122] \\
\hline & Phenol, & & 4.9 & & \\
\hline Granular activated carbon & 2-chlorophenol & 50 & 4.3 & $60 \mathrm{~min}$ & [123] \\
\hline$(\mathrm{GAC})$ & 4-chlorophenol & & 4.5 & & \\
\hline Red pine AC & & & 454.5 & & \\
\hline Yellow poplar AC & Phenol & 200 & 625 & $30 \mathrm{~min}$ & {$[61]$} \\
\hline Commercial AC & & & 500 & & \\
\hline
\end{tabular}

Generally, AC produced from agricultural wastes displayed better removal capacity and shorter equilibrium time for the adsorption of PAHs and phenols in the aqueous medium as compared to biochar. This is perhaps associated with the higher porosities of the AC. However, in terms of sources, biochar can be generated from different varieties and abundant agricultural waste feedstocks [70]. Additionally, from economic point of view, biochar has cheaper production cost than the AC. Unlike in the latter, the former consumes less energy and activation is necessary in most cases [79]. However, both materials are considered superior to raw biomass in their affinity towards PAHs and phenols [124]. In both cases, the adsorption occurs via hydrogen bonding and $\pi-\pi$ electron- donor-acceptor interactions between the active sites on the surface of the $\mathrm{AC}$ with the benzene rings of the organic pollutants and the functional groups on the phenol as seen in the Figure 3. For both AC and biochar, better removal capacities are achieved by surface modifications of the porous carbon materials. Additionally, the surface modifications could result in more stable adsorbents [98]. 


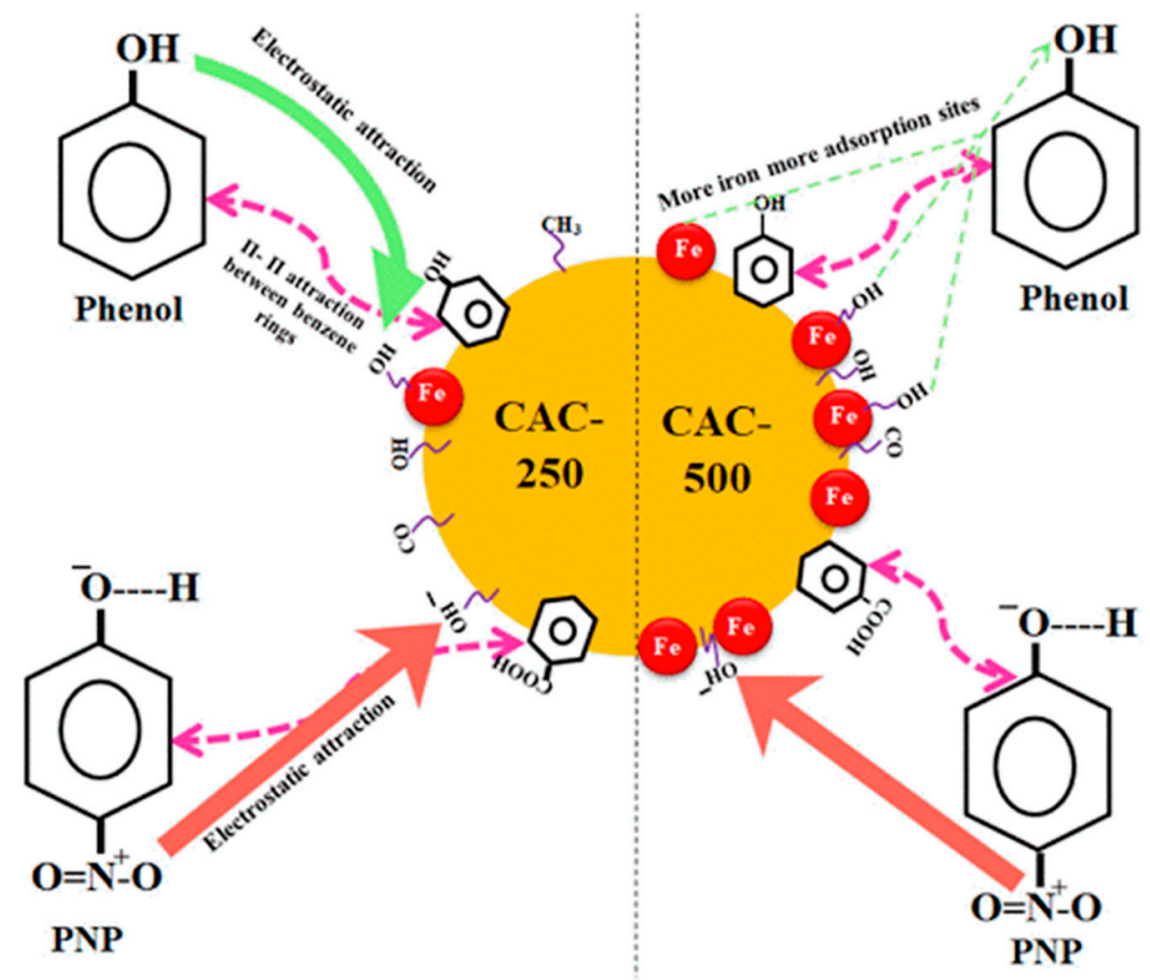

Figure 3. Mechanism for the adsorption of phenols onto activated carbons via hydrogen bonding and $\pi-\pi$ interactions [125]. Copyright: Korean Society of Chemical Engineers (2020).

\subsection{Other Porous Carbon Materials as Adsorbents for PAHs and Phenols}

Apart from biochar and $\mathrm{AC}$, other porous carbon nanomaterials such as graphene, carbon nanotubes (CNTs), nanohorns, nanofibers, fullerenes, soot, molecular carbon sieves, and other carbonaceous-derived materials [126] have been studied. They are chemically heterogenous and high carbon content materials that are usually obtained from either partial or complete combustion of plant materials [127]. Many of the carbon-based nanomaterials have been investigated as adsorption material for water remediation. The most widely employed are graphene and CNTs. They are recognized with extra-ordinary physical and chemical properties that are superior to other carbon-based materials. They possess good chemical and thermal stability with much higher surface area than AC and biochar [62,128]. Their improved surface properties allow them to interact with organic pollutants via covalent and non-covalent bond formation such as hydrogen bonding, electrostatic forces, $\pi-\pi$ stacking, van der Waals forces, and hydrophobic interactions [14].

\subsubsection{Graphene, Graphene Oxides, and Reduced Graphene Oxides}

Graphene is a form of nanomaterial having a honeycomb-like structure of $\mathrm{sp}^{2}$ hybridized carbon atoms with single atom of graphite layer. The allotrope of graphene is called graphite, having a planar structure [129]. It exhibits outstanding physical and chemical properties, such as good electrical and thermal conductivity, high strength, high specific surface area and pore volumes, flexibility, and negligible thickness $[130,131]$. Apart from that, graphene chemical mobility, which allow for its modification to form other functionalized advanced carbon materials. Graphene oxides (GOs) and reduced graphene oxide ( $\mathrm{rGO}$ ) are among the most advanced graphene-based engineering materials (Figure 4) [132,133] They are regarded as the fascinating forms of graphene materials and thus have versatile applications in various fields such as biomedicines, sensors, metrology, electronic devices, as well as environmental pollutant's remediation in environmental waters [134]. 


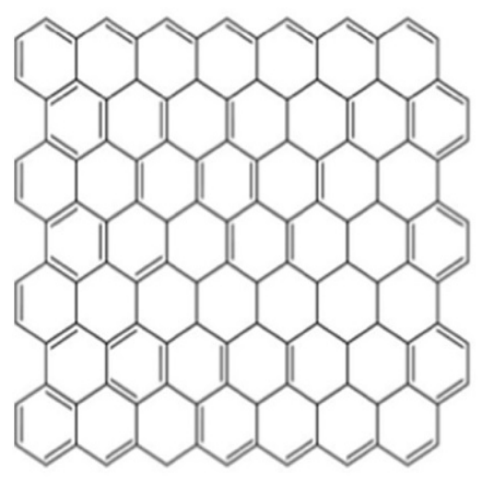

(a)

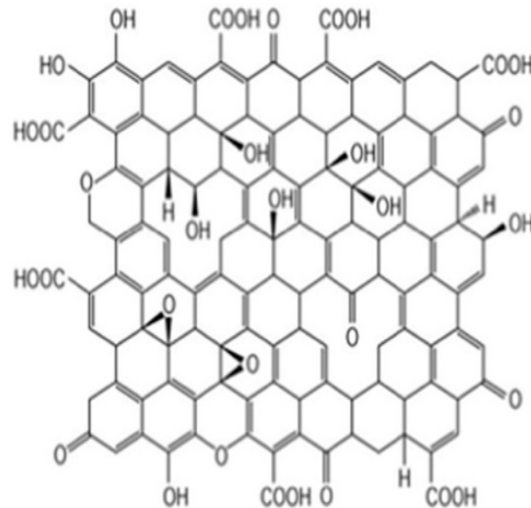

(b)

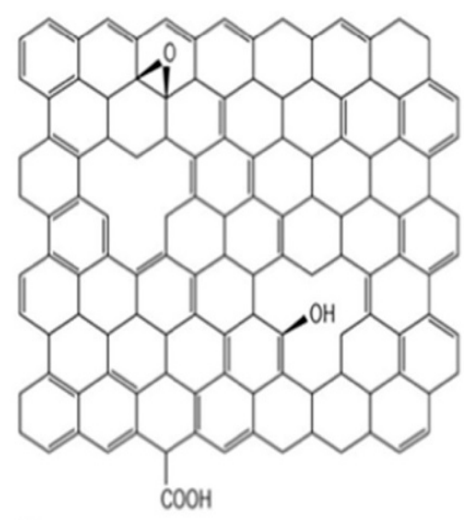

(c)

Figure 4. Chrystal structures of (a) graphene, (b) graphene oxide, and (c) reduced graphene oxide [133]. Copyright: Elsevier (2020).

In adsorption studies, their unique chemical properties and high specific surface area has been emphasized. Sun et al. (2013), has reported on the batch adsorptions of NAP, ANT, NAP, and PYR onto graphite, GOs and RGOs. The performance of the materials in decreasing order were rGOs > GOs > graphite, with the former having adsorption capacities of 15.92, 247.17, and $369.06 \mathrm{mg} / \mathrm{g}$ for NAP, ANT, and PYR, respectively [135]. Recently, application of graphene wool for the removal of PHE and PYR from aqueous environment has been reported by Adedapo et al. (2019). Effective removal of 99.9 and $99.1 \%$ were achieved for PHE and PYR respectively, within 24 h of contact between the PAHs and the adsorbent. The adsorbent material can be repeatedly used with little or no decreased in percentage removals over 8 successive cycles [136].

In the case of phenols removal, graphene and functionalized graphene materials have been reportedly used as adsorbents. Zhou et al. (2017) reported on the fabrication of graphene composite $\mathrm{Fe}_{3} \mathrm{O}_{4} @$ PANI-GO for the batch removal of bisphenol A, $\mathrm{t}$-octyl phenol and $\alpha$-naphthol in water. The complete removal of the pollutants within shortest time $(5 \mathrm{~min})$ for bisphenol A, $t$-octyl phenol respectively, whereas the $\alpha$-naphthol experienced slightly longer time, (300 $\mathrm{min}$ ) to equilibrium. The promising application of the material was demonstrated by its effective reusability (10 successive cycles) without decreased in the removal capacity of the pollutants [137]. The report of Wang et al., (2018) have shown that the adsorption of phenols pollutants; 2-phenylphenol (PPE), bisphenol A (BPA), 4-isopropylphenol (IPE), 4-methylphenol (ME), and phenol (PE) were more effective onto the rGO (Figure 5) as compared to the GO, attributed to the decreased in electron density in the latter, hence the strong $\pi-\pi$ interactions between the phenols and the adsorbent [138]. Tian et al. (2019), reported on the rapid adsorption of bisphenol A $(3.4 \mathrm{~s})$, onto hybrid material of graphene oxide with amino functionalized polypropylene (PP-g-DMAEMA/GO). The adsorbent possessed dual channel structure which allows bisphenol A to easily access the surface of the GO through the nanochannels of the propylene molecule [139].

In most cases, graphene was shown to have better performance in terms of adsorption capacity as compared to GO and rGO. In comparison to $\mathrm{rGO}, \mathrm{GO}$ has more oxygen containing functional groups and lesser $\pi$ electron density [138]. It has been established that the hydrophobic effects of the organic contaminants were the reasons for their strong absorption onto the graphene which occur though $\pi-\pi$ interactions $[63,140]$. In the case of $\mathrm{GO}$, the dense carbonyl groups at the edge of the carbon layers were responsible for the strong adsorption of hydrophobic organic pollutants onto the surface of the material through electrostatic, hydrogen bonding, and anion- $\pi$ interactions. More details of the adsorptions of PAHs and phenols onto the graphene, GO, rGO, and their derivatives have been highlighted in Table 6. 

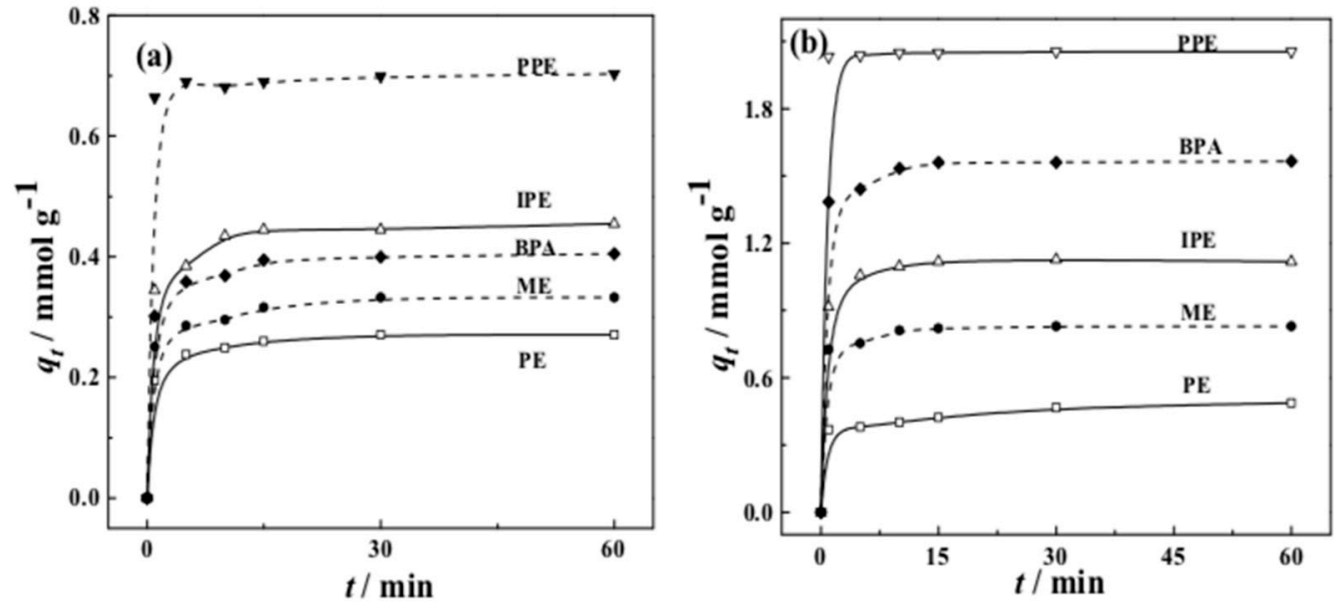

Figure 5. Adsorption capacity (a) graphene and (b) graphene oxide for phenols removal. Reproduced from ref [138].

Table 6. Adsorptions of PAHs and phenols onto graphene, GO and reduced graphene oxide (rGO) and their composites.

\begin{tabular}{|c|c|c|c|c|c|}
\hline Adsorbent & Pollutant & $\begin{array}{l}\text { Concentration } \\
(\mathrm{mg} / \mathrm{L})\end{array}$ & $\underset{(\mathrm{mg} / \mathrm{g})}{\mathrm{Q}_{\mathrm{e}}}$ & $\begin{array}{l}\text { Equilibrium } \\
\text { Time }\end{array}$ & Ref \\
\hline \multirow{3}{*}{ Graphene wool } & PHE & 0.8 & 5 & & \\
\hline & PYR & 5 & 200 & $24 \mathrm{~h}$ & [126] \\
\hline & NAP & 30 & 16 & & \\
\hline \multirow[t]{2}{*}{$\mathrm{rGO}$} & ANT & 0.05 & 247 & 7 days & [125] \\
\hline & PYR & 0.1 & 369 & & \\
\hline \multirow{2}{*}{$\begin{array}{c}\mathrm{GO} / \mathrm{FeO} \cdot \mathrm{Fe}_{2} \mathrm{O}_{3} \\
\text { Graphene } \\
\text { GO }\end{array}$} & NAP & 0.1 & 6 & $48 \mathrm{~h}$ & [64] \\
\hline & NAP & 4.6 & $\begin{array}{c}1 \\
66\end{array}$ & $4 \mathrm{~h}$ & [63] \\
\hline $\begin{array}{l}\text { Graphene } \\
\text { GO }\end{array}$ & NAP & - & $\begin{array}{l}9 \\
8\end{array}$ & $10 \mathrm{~min}$ & [141] \\
\hline Sulfonated graphene & NAP & 0.39 & 2 & 5 days & [142] \\
\hline rGO@Sand & NAP & 0.8 & 4 & $120 \mathrm{~min}$ & [143] \\
\hline Magnetic graphene nanosheet & $\begin{array}{l}\text { ACE } \\
\text { PHE }\end{array}$ & 0.5 & $\begin{array}{c}6 \\
0.02 \\
14\end{array}$ & $1 \mathrm{~h}$ & [72] \\
\hline \multirow{2}{*}{$\begin{array}{l}\text { Magnetic chemically GO } \\
\text { Magnetic rG }\end{array}$} & PHE & 1 & 30 & $24 \mathrm{~h}$ & [60] \\
\hline & PHE & 4.2 & 1.2 & & \\
\hline \multirow[t]{2}{*}{$\mathrm{TiO}_{2}$-Graphene } & FLAN & 4.5 & 0.9 & $180 \mathrm{~min}$ & [59] \\
\hline & $\mathrm{BaP}$ & 2.5 & 0.5 & & \\
\hline GO & & & 21 & & \\
\hline rG & NAP & 20 & 52 & $24 \mathrm{~h}$ & [144] \\
\hline \multirow{2}{*}{ Reduced graphene } & & & 145 & & \\
\hline & Bisphenol A & 5 & 14 & $5 \min$ & \\
\hline \multirow[t]{4}{*}{$\mathrm{Fe}_{3} \mathrm{O}_{4} @ \mathrm{PANI}-\mathrm{GO}$} & t-octyl phenol & 5 & 31 & $5 \min$ & [137] \\
\hline & $\alpha$-naphthol & 10 & 23 & $300 \min$ & \\
\hline & 2-phenylphenol & 0.470 & 12 & $60 \mathrm{~min}$ & \\
\hline & bisphenol A & 0.350 & 1.56 & & \\
\hline \multirow[t]{3}{*}{ rGO } & 4-isopropylphenol & 0.587 & 1.117 & & [138] \\
\hline & 4-methylphenol & 0.550 & 0.841 & & \\
\hline & phenol & 0.850 & 0.483 & & \\
\hline CTAB-modified graphite & bisphenol A & 300 & 125 & $10 \mathrm{~min}$ & [129] \\
\hline Amino-functionalized GO & Bisphenol A & 1 & 2.3 & $3.4 \mathrm{~s}$ & [139] \\
\hline
\end{tabular}


Table 6. Cont

\begin{tabular}{|c|c|c|c|c|c|}
\hline Adsorbent & Pollutant & $\begin{array}{l}\text { Concentration } \\
(\mathrm{mg} / \mathrm{L})\end{array}$ & $\begin{array}{c}Q_{e} \\
(\mathrm{mg} / \mathrm{g})\end{array}$ & $\begin{array}{c}\text { Equilibrium } \\
\text { Time }\end{array}$ & Ref \\
\hline rGO & phenol & 50 & 16 & & \\
\hline $\mathrm{GO}$ & $\begin{array}{c}\text { bisphenol A } \\
\text { 4-nonylphenol } \\
\text { tetrabromobisphenol } \\
\text { A } \\
\text { 2,4,6-trichlorophenol }\end{array}$ & 20 & $\begin{array}{l}21 \\
10 \\
11 \\
18\end{array}$ & $1400 \mathrm{~min}$ & [14] \\
\hline Graphene & 4-chloro-2-nitrophenol & 10 & 25 & $60 \mathrm{~min}$ & [145] \\
\hline $\begin{array}{l}\mathrm{GO} \\
\mathrm{rGO}\end{array}$ & Phenol & 50 & $\begin{array}{c}23 \\
16.32\end{array}$ & $100 \mathrm{~min}$ & [146] \\
\hline MGO-IL & phenol & 30 & 741 & $12 \mathrm{~min}$ & [147] \\
\hline Graphene & Bisphenol A & 10 & 87 & $5 \mathrm{~h}$ & [62] \\
\hline Sulfonated graphene & 1-naphthol & 0.7 & 2.41 & 5 days & [142] \\
\hline Graphene & phenol & 50 & 28 & $400 \mathrm{~min}$ & [148] \\
\hline $\begin{array}{l}\text { GO sheet } \\
\text { GO sponge }\end{array}$ & 2,4,6-trichlorophenol & 5 & $\begin{array}{l}10 \\
21\end{array}$ & $\begin{array}{l}30 \mathrm{~min} \\
12 \mathrm{~min}\end{array}$ & [149] \\
\hline GO & Bisphenol A & - & 49 & $30 \mathrm{~min}$ & [150] \\
\hline $\mathrm{GO}$ & $\begin{array}{l}\text { tetrabromobisphenol } \\
\text { A }\end{array}$ & 1 & 41 & $120 \mathrm{~min}$ & [151] \\
\hline GO & p-nitrophenol & 200 & 138 & $24 \mathrm{~h}$ & [51] \\
\hline GO & & & 21 & & \\
\hline Chemically GO & 1-naphthol & 50 & 52 & $24 \mathrm{~h}$ & [144] \\
\hline $\mathrm{rG}$ & & & 145 & & \\
\hline $\mathrm{GO}$ & & & 32 & & \\
\hline $\begin{array}{c}\text { Ultrasonic GO } \\
\text { Conventional GO }\end{array}$ & 2-chlorophenol & 50 & $\begin{array}{c}134 \\
50\end{array}$ & $50 \mathrm{~min}$ & [152] \\
\hline Ultrasonic GO & & & 209 & & \\
\hline
\end{tabular}

\subsubsection{Carbon Nanotubes (CNTs)}

CNTs are sheets of pure form of carbon atoms covalently bonded to one another in hexagonal arrays which are rolled into a hollow cylindrical shape, with the outer diameter ranging between 1-100 nm, while the size up to several tens of micrometers [153]. Since its discovery in 1992, CNT have been identified with unique physical and chemical properties such as high strength and specific gravity, good conductivity and thermal stability, high porosity [154,155], making them potential materials have for various applications such as in optical appliances, energy conversion, electrochemical sensors, catalyst and adsorbent, micro analytical devices, biomedical devices, and drug delivery [156,157]. The application of CNTs in environmental remediation have also been investigated [158,159]. CNTs have been employed as potential adsorbents for organic and inorganic pollutants removal from wastewater due to its superior properties and more tailored surface chemistry, presenting higher surface porosities and strong chemical and physical interactions with the organic pollutants than the AC and corresponding carbon-derived adsorbents $[160,161]$. The surface morphology of the CNTs and the functional groups present in the organic pollutant has been contributing factor for their higher affinity for the pollutants, thus, rapid removal with higher adsorption capacities [162].

The potential of CNTs for environmental remediation of organic pollutants has been well studied. Wu et al. (2016) explored on the affinity of various aromatic compounds onto CNTs. About 22 different organic pollutants including phenols, substituted benzenes, and PAHs, have been considered and the findings confirmed positive correlations between the adsorption capacities of the CNTs based on their mesoporous surfaces to the properties of the pollutants [163]. A review on the prospects and applications of carbon nanostructured materials in water treatment was presented by Selvaraj et al. (2020) [164]. Apur et al. (2015) discussed the adsorption of organic pollutants including PAHs and phenols onto the CNTs [165]. Another report was presented by Ahmad et al. (2019) on the removal 
of organic pollutants in wastewater by CNTs [166]. The preparations, properties, and modifications of the CNTs have been discussed. The adsorptions of PAHs, pharmaceutical and personal care products, surfactants and pesticides has been explored and the nature of the interactions between the pollutants and the CNTs has been highlighted. However, in most of the review articles written detailed of the optimized adsorption conditions of phenols and PAHs onto the CNTs were not mentioned.

Earlier work on the removal of PAHs from wastewater was conducted by Yang et al. (2006) using commercially obtained single-walled carbon nanotubes (SWCNTs) and multi-walled carbon nanotubes (MWCNTs). The adsorptions were found to be $\mathrm{pH}$ independent due to the neutral nature of the PAHs [167]. The adsorption modeling of PAHs onto CNTs has been studied by Kah et al. (2011). Various concentrations of the PAHs were analyzed, achieving higher adsorption capacities at both lower and higher concentrations, attributed to the higher surface area of the CNTs in the range of 200-500 $\mathrm{m}^{2} / \mathrm{g}$ [168]. Zhang et al. (2019) reported the use of magnetic CNTs for the removal of PHE from water. The magnetization of the CNTs has been shown to increase the removal efficiency as well as ease of the regeneration and reusability of the adsorbents [72]. The non-linearity of the PAHs and their non-ionic and hydrophobic nature, enable them to interact with CNTs through $\pi-\pi$ bonding [169]. Hybrid simulation analysis was employed by Yali et al. (2019) to predict the adsorption coefficient of PAHs onto MWCNT using quantitative structure-property relationship (QSPR) using genetic algorithm-multiple linear regression (GA-MLR). The data was subjected to training and testing. The explanation given was that the electrostatic and steric parameters of PAHs were the major factors responsible for the higher adsorption capacities for the MWCNT. Hence the molecular docking simulation was accurate and reliable to predict the sorption efficiency [170]. Wu et al. (2020), studied the sorption mechanisms for PAHs onto CNTs through density functional theory (DFT) and molecular dynamics simulation. The sorption energies for the individual PAHs (NAP and PHE, -33.48 and $-42 \mathrm{kcal} / \mathrm{mol}$, respectively) were calculated from the compass force field. The simulation studies were able to predict that CNTs and PAHs interacted through $\pi-\pi$ stacking and the Van der Waals interactions [171].

For the adsorption phenol onto CNTs, researchers have identified multiple interactions via $\pi-\pi$, hydrogen bonds, and electrostatic interactions. Kragulj et al. (2015) reported on the removal of chlorinated phenols (2,4-dichlorophenols, 2,4,6-trichlorophenols, and 2,3,4,5-tetrachlorophenols) onto originally synthesized MWCNT via catalytic chemical vapor deposition (CCVD) and acid functionalization (FMWCNTs). The FMWCNTs has outstanding performance compared to the pristine form as shown by the increased in the BET surface area functionalization $\left(61.3 \mathrm{~m}^{2} / \mathrm{g}\right.$ and $600 \mathrm{~m}^{2} / \mathrm{g}$ for MWCNT and FMWCNT, respectively). Except for 2,4,6-trichlorophenol, which was slightly lower than 2,4-dichlorophenol, the adsorption was found to be positively correlated with molecular weight of the pollutants [172]. The mechanism for phenol adsorption onto SWCNTs and MWCNTs using quantum mechanics molecular modeling was investigated by Rezakazemi et al. (2018) [136]. The strong affinity of CNTs onto the phenols has been emphasized by the formation of $\pi-\pi$ interactions between the delocalized $\pi$ electrons in the surface of the $\mathrm{sp}^{2}$ hybridized carbon structure of the CNTs. However, modified CNTs such as oxidized CNT (CNTO) can form hydrogen bonding with the phenol, thus better affinity than the pristine CNT (Figure 6). Other factors affecting the adsorption of phenols onto the CNTs include $\mathrm{pH}$, ionic strength, as well as the dispersion of the CNTs in the solution. Table 7 discussed the adsorptions of phenols and PAHs onto various CNTs. 


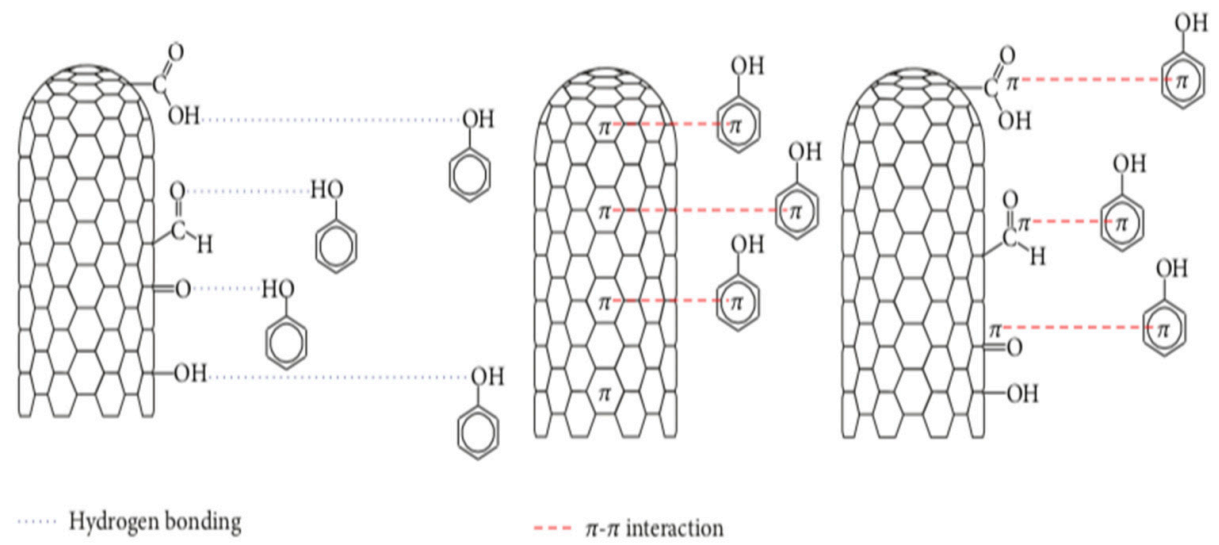

Figure 6. Schematic diagram for the mechanism of phenol adsorption onto carbon nanotubes (CNT). Reproduced from ref [146].

Table 7. Adsorptions of PAHs and phenols onto CNTs and their composites.

\begin{tabular}{|c|c|c|c|c|c|}
\hline Adsorbent & Pollutant & $\begin{array}{l}\text { Concentration } \\
(\mathrm{mg} / \mathrm{L})\end{array}$ & $\underset{(\mathrm{mg} / \mathrm{g})}{Q_{\mathrm{e}}}$ & $\begin{array}{c}\text { Equilibrium } \\
\text { Time }\end{array}$ & Ref \\
\hline MWCNT & NAP & 200 & 69.2 & 5 days & [173] \\
\hline \multirow{3}{*}{ Commercial MWCNT } & NAP & & 10.9 & \multirow{3}{*}{5 days } & \multirow{3}{*}{ [167] } \\
\hline & PHE & - & 10.6 & & \\
\hline & PYR & & 10.6 & & \\
\hline Magnetic SWCNT & \multirow{2}{*}{ PHE } & \multirow{2}{*}{500} & 24.82 & \multirow{2}{*}{$30 \mathrm{~min}$} & \multirow{2}{*}{ [72] } \\
\hline Magnetic MWCNT & & & 19.37 & & \\
\hline \multirow{2}{*}{ MWCNT } & phenol & 0.147 & 0.13 & \multirow{2}{*}{3 days } & \multirow{2}{*}{ [174] } \\
\hline & 3-chlorophenol & 1.25 & 0.38 & & \\
\hline CNT-polymer bead & p-chlorophenol & 100 & 24 & $1200 \mathrm{~min}$ & [71] \\
\hline CNT-polyethylene glycol & phenol & 20 & 27 & $40 \mathrm{~min}$ & [54] \\
\hline CNT-polymer composite & phenol & 30 & 262 & $50 \mathrm{~min}$ & [162] \\
\hline SWCNT & \multirow{2}{*}{ phenol } & \multirow{2}{*}{50} & 51 & $54 \mathrm{~min}$ & \multirow{2}{*}{ [127] } \\
\hline MWCNT & & & 65 & $36 \mathrm{~min}$ & \\
\hline $\mathrm{CNT}$ & \multirow{2}{*}{ phenol } & \multirow{2}{*}{2} & 1.1 & $2 \mathrm{~h}$ & \multirow{2}{*}{ [175] } \\
\hline $\mathrm{CNT}-\mathrm{Fe}_{2} \mathrm{O}_{3}$ & & & 2.8 & $2 \mathrm{~h}$ & \\
\hline Magnetic- $\mathrm{N}_{2} \mathrm{H}_{4}-\mathrm{SH} / \mathrm{MWCNT}$ & phenol & 40 & 39 & $700 \mathrm{~min}$ & [176] \\
\hline \multirow[t]{2}{*}{ Chitosan hydrogel-CNT } & phenol & \multirow[t]{2}{*}{200} & 404 & $120 \mathrm{~min}$ & \multirow[t]{2}{*}{ [177] } \\
\hline & phenol & & 1.1 & & \\
\hline \multirow{3}{*}{$\begin{array}{c}\mathrm{CNT} \\
\mathrm{CNT}-\mathrm{Al}_{2} \mathrm{O}_{3}\end{array}$} & 4-chlorophenol & \multirow{3}{*}{2} & 1.3 & \multirow{3}{*}{$120 \mathrm{~min}$} & \multirow{3}{*}{ [34] } \\
\hline & phenol & & 2.8 & & \\
\hline & 4-chlorophenol & & 2.8 & & \\
\hline \multirow{5}{*}{$\begin{array}{c}\text { CNT } \\
\text { CNT-deep eutectic solvent } \\
\text { Chitosan-MWCNT }\end{array}$} & phenol & \multirow{2}{*}{50} & 62 & \multirow{2}{*}{$24 \mathrm{~h}$} & \multirow{2}{*}{ [13] } \\
\hline & рпепол & & 120 & & \\
\hline & phenol & 150 & 88 & $24 \mathrm{~h}$ & [17] \\
\hline & phenol & & 24 & $50 \mathrm{~min}$ & \\
\hline & 2-chlorophenol & & 86 & $50 \mathrm{~min}$ & \\
\hline $\mathrm{CNT}$ & 4-chlorophenol & 150 & 52 & $30 \mathrm{~min}$ & [178] \\
\hline CNT-activated & phenol & 150 & 64 & $50 \mathrm{~min}$ & {$[1 / 8]$} \\
\hline & 2-chlorophenol & & 240 & $50 \mathrm{~min}$ & \\
\hline & 4-chlorophenol & & 105 & $30 \mathrm{~min}$ & \\
\hline MWCNT & bisphenol A & 0.37 & 111 & 3 days & [179] \\
\hline MWCNT & phenol & 25 & 32 & $300 \mathrm{~min}$ & [180] \\
\hline SWCNT & & & 20 & & \\
\hline SWCNTO & & & 21 & & \\
\hline MWCNT & phenol & 50 & 18 & $100 \mathrm{~min}$ & [146] \\
\hline MCNTO & & & 16 & & \\
\hline CNT-Mg-Al hydroxide & phenol & 50 & 13 & & [181] \\
\hline MWCNT & $\begin{array}{l}\text { 4-chlorophenol } \\
\text { 2,4,6-trichlorophenol }\end{array}$ & 120 & $\begin{array}{l}14 \\
23\end{array}$ & $48 \mathrm{~h}$ & {$[182]$} \\
\hline
\end{tabular}


Thus, the efficiency of the carbon-based materials as adsorbents for PAHs and phenols removal has been well established. AC to a larger extent has been the most widely reported adsorbent. It has been prepared from the various agricultural waste materials under different conditions. Additionally, the commercial AC has been available in the markets. Thus, their removal efficiency towards the PAHs and phenols is superior to that of the corresponding biochar derived from similar agricultural waste. Generally, CNTs have been shown to offer better removal efficiency than their corresponding graphene adsorbents. This is attributed to their remarkable high surface area. The strong affinity of the materials to the pollutants is made possible by the presence of hydrogen and $\pi-\pi$ bonding interactions as illustrated in Figure 5.

\subsection{Other Porous Materials for PAHs and Phenols Adsorption}

Porous polymers (e.g., polymer beads, molecular imprinted polymers (MIPs)) [27], mesoporous chitosan [183], and advanced porous materials, such as mesoporous silica (examples; MCM-41, MCM-48 and SBA-15) [184], metal-organic frameworks (MOFs) [185], and other corresponding composites materials synthesized or are usually synthesized from other known materials. They have been known to possess physical and chemical properties superior to that of precursor components and that of the conventional porous materials. They have ultra-high porosity and surface area, high crystallinity, uniform surface morphology, high chemical and thermal stabilities, and other promising features. Thus, they have found numerous applications in various fields such as catalysis, gas storage, sensors, actuators, drug delivery, microextraction, and wastewater remediation [186,187].

The applications of synthesized polymers and advanced porous materials as adsorbents for PAHs and phenol removals have been investigated by various researchers. In most cases, the efficiency of these materials surpasses that of carbon-based materials such as AC, due to their larger pore size and volumes providing more adsorption sites for the pollutants $[188,189]$. Additionally, some of these materials have displayed good selectively for the PAHs and other phenolic compounds with the formation of hydrogen bonding and $\pi-\pi$ interactions.

\subsubsection{Chitosan}

The applications of chitosan, a polymer material obtained from the shell of seafoods and natural substances for adsorption of pollutants from wastewater have received considerable attention. The advantages of the material are the low-cost and large content of hydroxyl functional groups on the surface of the materials [190]. The price of commercial chitosan is much lower compared to that of the AC and zeolites and it can be easily synthesized with much less energy consumption [191]. The adsorptions of PAHs and phenols onto the chitosan are predominated by hydrogen bonding, hydrophobic, and $\pi-\pi$ interactions [192,193].

Bibi et al. (2015) used membranes synthesized from chitosan and poly vinyl pyrrolidone (CW) and carbon nanotube (CNT). The membranes with a surface area of 246 and $253 \mathrm{~m}^{2} / \mathrm{g}$ were used for the adsorption of NAP from aqueous solution. The membranes were applied for the adsorption of NAP from aqueous solution with the removal efficiency of 93 and $97 \%$ were achieved within 120 and $150 \mathrm{~min}$, respectively [194]. Crisafully et al. (2008) reported on the comparisons of various natural and commercial adsorbents materials including chitosan for the removal of PAHs [4]. Filho et al. (2018) reported on the synthesis of pectin/chitosan and pectin/chitosan/cyclodextrin polymers for the adsorption of 3 PAHs, PYR, B[b]F, and B[a]P. The adsorption of PAHs and phenols onto chitosan is summarized in Table 8. Efficient removal of the pollutants was achieved with good reusability of the adsorbents [195].

Alves et al. (2019) reported on the modification of chitosan with carbon nanotube composite with enhanced BET surface area of $1130 \mathrm{~m}^{2} / \mathrm{g}$ for the adsorption of phenol. Equilibrium was reached within $120 \mathrm{~min}$ with adsorption capacity of $404.2 \mathrm{mg} / \mathrm{g}$ [177]. A similar finding was reported Bahmani et al. (2019) using chitosan grafted with ZIF-8 for the phenol removal, achieving adsorption capacity of $152.3 \mathrm{mg} / \mathrm{g}$ within $30 \mathrm{~min}$ [196]. Guo et al. (2019) comprised the of adsorption of phenol using 
chitosan and MWCNT modified chitosan. The composite material achieved higher adsorption capacity of $(86.96 \mathrm{mg} / \mathrm{g})$ than the pristine chitosan with $(61.69 \mathrm{mg} / \mathrm{g})$ [17]. Karamipour et al. (2020) reported the adsorption of phenol using cellulose acetate/chitosan (CA/Chitosan) composite. The adsorption capacity achieved was $97.43 \mathrm{mg} / \mathrm{g}$ within $9 \mathrm{~h}$. A modification of the CA/Chitosan with iron (III) oxide, $\left(\mathrm{Fe}_{2} \mathrm{O}_{3}-\mathrm{CA} / \mathrm{Chitosan}\right)$ improved the physical stability of the adsorbent, achieving good reusability with the adsorption capacity to $163 \mathrm{mg} / \mathrm{g}$ [197].

\subsubsection{Molecularly Imprinted Polymers (MIPs)}

MIPs are obtained from the interactions of organic and or inorganic monomers of polymerizable capabilities which are assembled around a specific template known as the 'imprint', resulting into crosslinking of the monomers to form a solid framework [198]. They are well known for their high porosity resulting from the removal of the template molecules, forming large cavities allows for the easy access of the molecules to the recognition sites [27,199]. The MIPs of inorganic molecularly imprinted materials are more flexible in comparison to those obtained from the organic monomers due to the more availability of the inorganic monomers to be selected from, hence the rigidity of the solid network as well as the adaptable porosity [200].

The adsorptive properties of the MIP towards pollutants removals in wastewater has been emphasized on their large porosity, providing more adsorption sites for the pollutants [201], as highlighted in Table 6. They also offer high selectivity to the pollutants, mainly via hydrogen bonding, ion-pair interactions, hydrophobic interactions, and Van der Waals forces [28]. The adsorptions of PAHs onto the functionalized silica aerogels has been recently reported by Saad et al., (2020). The adsorbent material has proven to be effective in the removal of NAP, ANT, and PYR, with the fluorescence measurements showing effective adsorption and selectivity of the material in the highest order of NAP, ANT, and PYR, respectively [200]. Wei et al. (2015) reported on the selective recognition of PAHs by MIPs. In comparison to the hydrophilic MIP (H-MIP) and co-monomer glycidyl methacrylate (G-MIP), the conventional MIP has higher binding capacity to the PAHs, attributed to the hydrophobic nature of the material [202].

Bhatnagar and Anastopoulos (2017) reported the adsorption of bisphenol A and other phenolic compounds in water [190]. Bayramoglu et al. (2016) reported on the synthesis and selectivity of MIP and non-imprinted polymer (NIP) for the adsorption of bisphenol A, 4-aminophenol, p-toluidine, and 2-napthol in the binary and multiple component system. The adsorption capacity of bisphenol A for the MIP and NIP were 76.7 and $59.9 \mathrm{mg} / \mathrm{g}$, respectively, indicating the selectivity and removal efficiency of the latter [203]. Adsorptive recognition of phenolic compounds bisphenol A, phenol, 4-nitrophenol, 2-amino-4-chlorophenol and 2-napthol has been reported by Lyu et al. (2020), using MIP and ionic liquid mediated MIP (IL-MIP). Higher selective of the bisphenol A has been achieved by the IL-MIP as compared to the conventional MIP, attributed to the complementary of the imprinted cavity of the IL-MIP to the bisphenol structure [198].

Table 8. Adsorption of PAHs and phenols using chitosan and molecularly imprinted polymers (MIPs).

\begin{tabular}{|c|c|c|c|c|c|}
\hline Adsorbent & Pollutant & $\begin{array}{l}\text { Concentration } \\
(\mathrm{mg} / \mathrm{L})\end{array}$ & $\begin{array}{c}Q_{e} \\
(\mathrm{mg} / \mathrm{g})\end{array}$ & $\begin{array}{c}\text { Equilibrium } \\
\text { Time }\end{array}$ & Ref \\
\hline \multicolumn{6}{|c|}{ Chitosan } \\
\hline \multirow{3}{*}{ Pec- $\beta-C D /$ Chitosan } & PYR & & 0.1 & & \\
\hline & $\mathrm{B}[\mathrm{b}] \mathrm{F}$ & 2 & 0.2 & $1200 \mathrm{~min}$ & [195] \\
\hline & $\mathrm{B}[\mathrm{a}] \mathrm{P}$ & & 0.2 & & \\
\hline Chitosan & phenol & & & & \\
\hline \multirow[t]{2}{*}{ Chitosan/CNT } & phenol & 400 & 404 & $120 \mathrm{~min}$ & [177] \\
\hline & phenol & 150 & 34 & & \\
\hline \multirow[t]{2}{*}{ Chitosan-cyclodextrin } & p-chlorophenol & 157 & 180 & - & [193] \\
\hline & p-nitrophenol & 150 & 21 & & \\
\hline
\end{tabular}


Table 8. Cont.

\begin{tabular}{|c|c|c|c|c|c|}
\hline Adsorbent & Pollutant & $\begin{array}{l}\text { Concentration } \\
(\mathrm{mg} / \mathrm{L})\end{array}$ & $\underset{(\mathrm{mg} / \mathrm{g})}{\mathrm{Q}_{\mathrm{e}}}$ & $\begin{array}{l}\text { Equilibrium } \\
\text { Time }\end{array}$ & Ref \\
\hline chitosan-g-PNVCL/ZIF-8 & Phenol & 20 & 152 & $30 \mathrm{~min}$ & [196] \\
\hline $\begin{array}{c}\mathrm{CA} / \text { Chitosan } \\
\mathrm{Fe}_{2} \mathrm{O}_{3}-\mathrm{CA} / \text { Chitosan }\end{array}$ & phenol & 100 & $\begin{array}{c}97 \\
163\end{array}$ & $5 \mathrm{~h}$ & [197] \\
\hline $\begin{array}{l}\text { Chitosan } \\
\text { MWCNT-Chitosan }\end{array}$ & phenol & 150 & $\begin{array}{l}62 \\
87\end{array}$ & $24 \mathrm{~h}$ & [16] \\
\hline & phenol & & 243 & & \\
\hline Fe-EDA/ $\beta-C D / C h i t o s a n$ & $\begin{array}{l}\text { p-nitrophenol } \\
\text { p-cresol }\end{array}$ & 50 & $\begin{array}{l}274 \\
298\end{array}$ & $120 \mathrm{~min}$ & [204] \\
\hline Magnetic chitosan & phenol & 15 & 52 & $50 \mathrm{~min}$ & [19] \\
\hline Resin-chitosan & $\begin{array}{l}\text { phenol } \\
\text { 4-chlorophenol }\end{array}$ & 50 & $\begin{array}{c}189 \\
99\end{array}$ & $\begin{array}{l}200 \mathrm{~min} \\
350 \mathrm{~min}\end{array}$ & [205] \\
\hline EDTA/Chitosan/ $\mathrm{TiO}_{2}$ & phenol & 50 & 209 & $240 \mathrm{~min}$ & [206] \\
\hline Chitosan-Carbon composite & phenol & 10 & 34 & $1 \mathrm{~h}$ & \\
\hline $\begin{array}{c}\text { Magnetic } \\
\text { graphene-Chitosan }\end{array}$ & 2-napthol & 40 & 169 & $60 \mathrm{~min}$ & [207] \\
\hline & $\begin{array}{l}\text { phenol } \\
\text { 2-chlorophenol }\end{array}$ & & $\begin{array}{l}60 \\
71\end{array}$ & & \\
\hline$\beta$-cyclodextrin-chitosan & $\begin{array}{l}\text { 4-chlorophenol } \\
\text { 2,4-dichlorophenol } \\
\text { 2,4,6-trichlorophenol }\end{array}$ & 120 & $\begin{array}{c}96 \\
315 \\
376\end{array}$ & $3 \mathrm{~h}$ & [22] \\
\hline Magnetic-Chitosan & bisphenol A & 100 & 55 & $120 \mathrm{~min}$ & [208] \\
\hline Glutaraldehyde-Chitosan & phenol & 50 & 21 & $60 \mathrm{~min}$ & [209] \\
\hline & $\begin{array}{c}\text { phenol } \\
\text { o-chlorophenol }\end{array}$ & 100 & $\begin{array}{l}71 \\
51\end{array}$ & $240 \mathrm{~min}$ & [210] \\
\hline \multicolumn{6}{|c|}{ MIPs } \\
\hline & $\mathrm{BaP}$ & & 75.9 & & \\
\hline MIP & $\begin{array}{l}\text { PYR } \\
\text { CHR }\end{array}$ & 1 & $\begin{array}{l}7 \\
7\end{array}$ & $3 \mathrm{~h}$ & [211] \\
\hline MIP & PHE & 0.6 & 16 & $90 \min$ & [212] \\
\hline MIP & PYR & 1 & 11 & $90 \min$ & [213] \\
\hline MIP & bisphenol A & 150 & 77 & $120 \min$ & [203] \\
\hline $\begin{array}{c}\text { vermiculite MP } \\
\text { magnetic vermiculite MP }\end{array}$ & $\begin{array}{l}\text { bisphenol A } \\
\text { phenol }\end{array}$ & 1000 & $\begin{array}{c}217 \\
274 \\
86\end{array}$ & $90 \mathrm{~min}$ & [214] \\
\hline Surface-MIP & $\begin{array}{c}\text { p-nitrophenol } \\
\text { p-tert-butylphenol }\end{array}$ & 0.75 & $\begin{array}{l}8 \\
7\end{array}$ & $4 \mathrm{~h}$ & {$[50]$} \\
\hline $\mathrm{MIP} / \mathrm{PES} / \mathrm{SiO}_{2}$ & $\begin{array}{l}\text { phenol } \\
\text { p-nitrophenol }\end{array}$ & 4000 & $\begin{array}{l}47 \\
37\end{array}$ & $8 \mathrm{~h}$ & [215] \\
\hline AMPS-Am-MIP & Phenol & 50 & 97 & $180 \mathrm{~min}$ & [18] \\
\hline $\begin{array}{c}\text { MIP } \\
\text { IL-MIP }\end{array}$ & Bisphenol A & 100 & $\begin{array}{c}87 \\
116\end{array}$ & $20 \min$ & [198] \\
\hline $\mathrm{Fe}_{3} \mathrm{O}_{4} @ \mathrm{SiO}_{2} @ P N P-S M I P$ & 4-nitophenol & 210 & 134 & $60 \mathrm{~min}$ & [216] \\
\hline $\begin{array}{l}\text { MIP } \\
\text { SMIP }\end{array}$ & bisphenol-A & 20 & $\begin{array}{l}24 \\
23\end{array}$ & $240 \mathrm{~min}$ & [217] \\
\hline
\end{tabular}

However, it should be stressed that pristine chitosan, upon long term usage as adsorbents, swells. This has drastically limited its application as potential adsorbent material in wastewater remediation. However, surface modification of the chitosan with other ideal functional materials helps to improve the performance of the material and improve its long-term usage. Some reported chitosan composites used for PAHs and phenols adsorption have been highlighted in Table 6.

\subsubsection{Mesoporous Silica}

With the advancement in nanotechnology and the attempted reproduction of silica nanoparticles in 1990 in Japan [218], researchers all over the world continue to explore the potential of the materials 
in various areas. Mesoporous nano silica particles such as Mobil Crystalline Materials (such as MCM-41 and MCM-48) and Santa Barbara Amorphous (such as SBA-15 and SBA-16) have been synthesized from rice husks, characterized and commercialized for various applications such as gas storage, drug delivery, oil-water separations, catalysis, and pollutant remediation [186].

Mesoporous silica has well-defined pore structures (hexagonal mesopores), narrow pore size distributions (4-12 nm), as well as high BET and Langmuir surface-area. Table 6 shows mesoporous silica that have been used for the PAHs and phenols adsorption. The adsorption capacity and equilibrium time have been stated.

Nasreen et al. (2018) synthesized highly porous mesoporous silica SBA-15 and MSU-H with BET surface area of 521 and 580 units, respectively. Both SBA-15 and MSU-H were found to be effective in the removal of NAP and PHE with the complete removal achieved within $20 \mathrm{~min}$ [218]. Costa et al. (2020) have reported the adsorptions of PAHs from aqueous solution using mesoporous silica MCM-41- $\mathrm{NH}_{2}$ that have been hydrothermally synthesized, possessing high retention rate of the pollutants with efficiency in the range of 93-98\% [219]. Comparison for the removal efficiency of MCM-48 and SBA-15 for the adsorption of NAP was investigated by Balati et al. (2014) with the latter having better efficiency, attributed to its higher larger pore diameter [220]. Yuan et al. (2018) investigated the mechanism for the PAHs adsorption onto the mesoporous silica. They have identified $\pi-\pi$ as the predominant interactions between the pollutants and the adsorbents [221].

The applications of mesoporous silica materials for phenols adsorptions has been investigated. Nasreen et al. (2018) reported that SBA-15 and MSU-H were able to adsorb 4-aminophenol and p-nitrophenol from the aqueous medium. The removal efficiency achieved was above $90 \%$ within $20 \mathrm{~min}$. It was suggested that the initial properties of the silica has been retained even after a series of regeneration and reusability, attributed to the high silicon content in the materials [218]. Highly porous mesoporous silica SBA-10 and PA-10 with a BET surface area of 925 and 353 m²/g were synthesized by Yangui et al. (2017) for the adsorption of phenolic compounds. Adsorption efficiency of $75 \%$ and $67 \%$ for phenol removal were reported within $2 \mathrm{~h}$ when the SBA-15 and PA-10 were modified with amine functional groups [222].

\subsubsection{Metal-Organic Frameworks (MOFs)}

The application of MOFs in wastewater remediation have recently gained more recognitions due to the great potential of these materials. They are made from the coordination interaction of the metal ion with organic moieties [223]. The metal node is the central building block, while organic moiety is the ligand and together forming a framework of higher tunability [224]. They are known to possess ultra-high porosity (over $90 \%$ by volume is empty) with BET surface area higher than that of AC and mesoporous silica (up to $9000 \mathrm{~m}^{2} / \mathrm{g}$ ) [225]. MOFs have higher crystallinity, thermal and moisture stability, and they can be easily regenerated from the aqueous medium through simple decantation or magnetic separation [226]. The topology of the framework also made it possible to modify the MOFs with other functional groups and materials for versatile and particular applications.

The use of MOFs for PAHs adsorptions recently been published by our groups [227]. The application of $\mathrm{Zr}$-based MOFs; $\mathrm{UiO}-66(\mathrm{Zr})$ and $\mathrm{NH}_{2}-\mathrm{UiO}-66(\mathrm{Zr})$ have been reported for ANT and CRY adsorptions from the aqueous medium. The BET surface area of the MOFs was 1420 and $985 \mathrm{~m}^{2} / \mathrm{g}$ for the UiO-66(Zr) and $\mathrm{NH}_{2}-\mathrm{UiO}-66(\mathrm{Zr})$, respectively. Higher removal efficiency has been achieved within short equilibrium time (25-30 min) with percentage removals of 98.6 and $97.9 \%$ for the ANT and CRY, respectively, using UiO-66(Zr) MOF. Interestingly, all the reported MOFs have displayed good reusability for the PAHs adsorption. We have also reported on the molecular docking interaction of the Fe-based MOFs, MIL-88(Fe) and $\mathrm{NH}_{2}-\mathrm{MIL}-88(\mathrm{Fe})$ with CRY. Figure 7 has illustrated the binding interaction of the MOFs with the CRY molecules with the MIL-88(Fe) having the most stable complex structure with the higher binding energy $\left(\Delta \mathrm{G}_{\text {bind }}\right)$ of $-3.88 \mathrm{kcal} / \mathrm{mol}$ and lower inhibition constant $(\mathrm{Ki})$ of $1.58 \mathrm{mM}$. Thus, the CRY molecules preferred to reside in the internal pores of the MOF. However, for the $\mathrm{NH}_{2}-\mathrm{MIL}-88(\mathrm{Fe})$, the binding energy is slightly lower, and the inhibition 
constant is higher, $-3.80 \mathrm{kcal} / \mathrm{mol}$ and $1.65 \mathrm{mM}$ respectively, resulting into lower binding stability of the complex. In the $\mathrm{NH}_{2}-\mathrm{MIL}-88(\mathrm{Fe})$, the CRY molecules preferred to adsorb on the outer pores of the MOFs. The high selectivity of the MIL-88(Fe) has been emphasized by the larger BET surface area and pore size of $1242 \mathrm{~m}^{2} / \mathrm{g}$ and $12.5 \mathrm{~nm}$ respectively. The BET surface area and the pore size of the $\mathrm{NH}_{2}-\mathrm{MIL}-88(\mathrm{Fe})$ was $941 \mathrm{~m}^{2} / \mathrm{g}$ and $8.8 \mathrm{~nm}$ respectively [228]. Table 9 highlights the various MOFs used for PAHs and phenols adsorptions in wastewater.

(a)

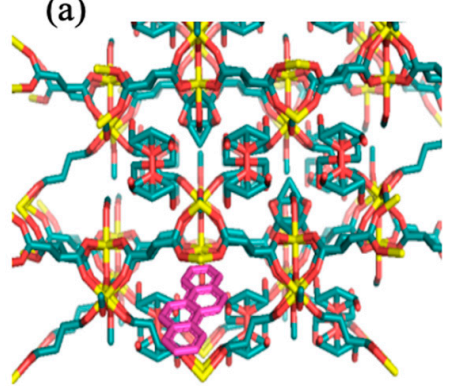

(b)

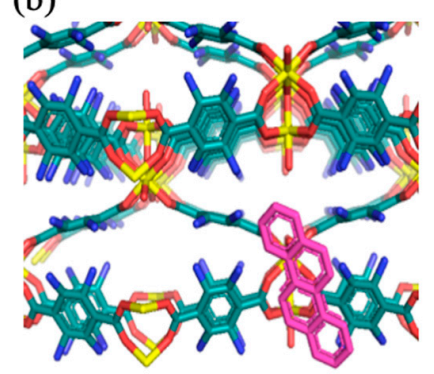

Figure 7. The molecular docking structure of (a) MIL-88(Fe) and (b) $\mathrm{NH}_{2}-\mathrm{MIL}-88(\mathrm{Fe})$ with the CRY molecule, for the binding interactions [229]. Copyright: Elsevier (2020). Metal (Fe), carbon (C), oxygen $(\mathrm{O})$, and nitrogen $(\mathrm{N})$ are colored as yellow, green, red, and blue, respectively. The CRY is indicated in purple.

Adsorptions of phenolic compounds onto MOFs have also been studied. Most of the reported MOFs are promising adsorbents for the removal of the pollutants studied. The famous HKUST-1 has shown good removal efficiency for the p-nitrophenol, with complete removal achieved within $40 \mathrm{~min}$ (equilibrium adsorption capacity of $400 \mathrm{mg} / \mathrm{g}$ ). The high adsorption capacity of the MOF for the p-nitrophenol was attributed to the high affinity of the MOF to the $\mathrm{NO}_{2}$ side of the pollutant, resulting into hydrogen bonding interactions [229]. The high selectivity and removal efficiency of the crystalline and water stable $\mathrm{Zr}$-based $\mathrm{MOF}, \mathrm{NH}_{2}-\mathrm{UiO}-66(\mathrm{Zr})$ for the adsorptions of 2,4,6-trinitrophenol, 2,4-dinitrophenol, 2,4,6-tri-nitrotoluene, and 2,4-dinitrotoluene in water was also investigated. Higher equilibrium adsorption capacities was achieved with the hydrogen bonding formation between the MOF and the pollutants [230]. Luo et al. (2019) reported on the enhanced removal of bisphenol A using Al-based composite Al-MOF/SA-CS. The adsorption capacity was $136 \mathrm{mg} / \mathrm{g}$. The adsorption mechanism has been explained by the formation of hydrogen bonding, $\pi-\pi$ stacking and cation- $\pi$ interactions [231].

Table 9. Adsorption of PAHs and phenols onto mesoporous silica and metal-organic frameworks (MOFs).

\begin{tabular}{cccccc}
\hline Adsorbent & Pollutant & $\begin{array}{c}\text { Concentration } \\
(\mathbf{m g} / \mathbf{L})\end{array}$ & $\begin{array}{c}\mathbf{Q}_{\mathrm{e}} \\
(\mathbf{m g} / \mathbf{g})\end{array}$ & $\begin{array}{c}\text { Equilibrium } \\
\text { Time }\end{array}$ & Ref \\
\hline & \multicolumn{2}{c}{ Mesoporous Silica } & & & \\
\hline MCM-41 & NAP & 15 & 61 & $20 \mathrm{~min}$ & {$[184]$} \\
& NAP & & 1.5 & & \\
Periodic mesoporous & ACE & 10 & 0.9 & & \\
organosilica & FLU & & 0.9 & $24 \mathrm{~h}$ & \\
& FLUO & & 0.7 & & \\
Fe-SBA-15 & PYR & 0.1 & 0.034 & $20 \mathrm{~min}$ & {$[188]$} \\
& PYR & & 1.9 & & \\
NH & NAP & 1 & 1.4 & $24 \mathrm{~h}$ & {$[232]$} \\
\hline
\end{tabular}


Table 9. Cont.

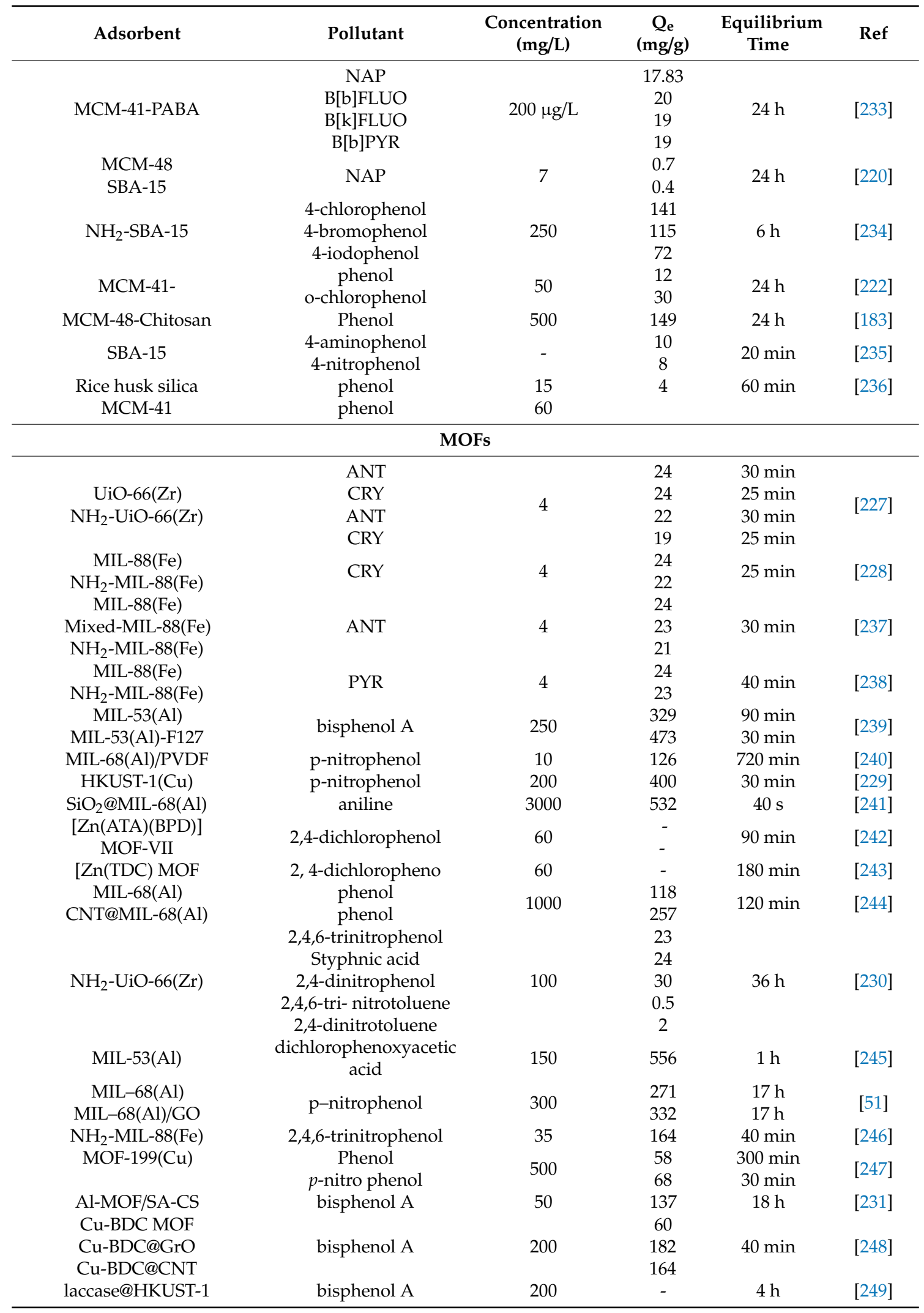




\subsection{Pilot and Industrial Scale Adsorption of PAHs and Phenol in Wastewater}

Pilot and industrial wastewater treatment plants have been the major repository of PAHs and phenols. In most cases, these pollutants are washed from the soil by heavy rain or directly emitted from petroleum refineries, petrochemical industries, and coal mining and processing areas. Thus, they are deposited into the municipal wastewater and wastewater treatment plants. Various studies have shown the presence of these pollutants at much higher concentrations than the maximum tolerable limit in the water. Thus, the target of wastewater remediation technologies has been the wastewater for both industrial and municipal treatment plants. Application of adsorption technologies at pilot and industrial wastewater has been well explored [250].

Activated carbon has been the adsorbent most widely used for the post-treatment of non-biodegradable pollutants such as PAHs and phenols in the wastewater treatment plants due to its large surface area and uniformity of surface microspores [251]. With the availability of various low-cost and highly porous adsorbents materials, some researchers have endeavored to explore the adsorptive removals of the PAHs and phenols at both pilot and industrial scale treatment plants. Kalmykova et al. (2014) have explored the performance of sand, granular activated carbon (GAC), and peat moss filters for PAHs and phenol adsorption at pilot-plant. The performance of each filter has been assessed with the GAC achieving complete removal of phenols, while the peat filter was able to remove $50-80 \%$ of the phenols. For PAHs removal, the percentage achieved by GAC and peat were $50 \%$ and $63 \%$, respectively [252]. The application of resin adsorbent, Amberlite XAD16, was reported by Frascari et al. (2016) for the removal of phenols from olive mill wastewater using continuous flow column at pilot-scale. The Amberlite XAD16 was well characterized with BET surface area of $800 \mathrm{~m}^{2} / \mathrm{g}$ and average particle size of $0.63 \mathrm{~mm}$. The adsorption capacity of the material was evaluated by the Langmuir model at $40 \mathrm{mg} / \mathrm{g}$ with over $70 \%$ removal efficiency achieved by the material [253]. El-Nass et al. (2016) have reported on the pilot-scale removal of phenol from refinery wastewater. About $250 \mathrm{~kg}$ of GAC with a particle size of $1.5 \mathrm{~mm}$ was used as the bed in the packed column of $1.8 \mathrm{~m}$ and $0.6 \mathrm{~m}$ length and internal diameter respectively. Over $90 \%$ removal of the phenols was achieved by the adsorbent, indicating the efficiency of GAC in removal of organic pollutants from the refinery wastewater [251].

\section{Conclusions}

Ubiquitous transport, distributions, and the fate of PAHs and phenols in wastewater has been a major environmental challenge for decades. These pollutants have been well identified as highly toxic to both fauna and flora and pose carcinogenic and mutagenic effects to humans. Hence, their environmental abatement, particularly from industrial, municipal, and wastewater treatment plants (WWTPs), has been highly desired. Various wastewater remediation technologies have been proposed. This article presented comprehensive review on the use of adsorption technology for PAHs and phenols remediation from water. The application of various porous adsorbents materials has been studied.

Porous carbon materials biochar and AC have discovered various applications in environmental remediation. Those materials have been successfully prepared from various agricultural wastes and been widely used as adsorbents for PAHs and phenols removal. In comparison to biochar, AC has shown more promising and potential removal capacity, attributed to the higher porosity of the AC. Apart from the biochar and AC, other derived porous carbons such as the graphene and CNTs have been widely employed. Their potentially higher removal efficiencies have been commended. This is attributed to their remarkable high surface area and strong affinity to the pollutants through the formation of hydrogen and $\pi-\pi$ bonding interactions, as we have illustrated.

Under similar conditions, the use of synthetic polymers, chitosan and MIPs, have been presented. Despite the selectivity of the polymers, the swelling effect of the chitosan limits their applications. However, modified chitosan has been shown to offer better removal capacity than the pristine form. To the larger extent, the potentials of advanced porous materials; mesoporous silica (such as MCM-41, 
MCM-48, and SBA-15), and MOFs had been discussed. The superior adsorption capacity of the silica and MOFs adsorbents had been in all way connected to their ultra-porosities and high stability of the materials. Their strong affinity to the PAHs and phenol has been highlighted.

Thus, application of various porous adsorbents has been presented. Findings from previous works from literature have been compiled and analyzed. This review thus highlighted the potential of adsorption technique for the removal of PAHs and phenols from environmental wastewater.

Author Contributions: Conceptualization, Z.U.Z. and N.S.S.; software, K.J.; validation, M.N.H.R.; formal analysis, H.A.I.; investigation, N.H.H.A.B.; resources, N.S.S.; data.; writing-original draft preparation, Z.U.Z.; writing-review and editing, A.R. and A.M.O.; visualization, A.S.; supervision, B.S.; project administration, N.S.S.; funding acquisition, N.S.S., A.R. All authors have read and agreed to the published version of the manuscript.

Funding: This research was funded by YUTP and UTP-UIR, grant number 015LCO-211 and 015MEO-166 and The APC was funded by King Khalid University.

Acknowledgments: We would like to acknowledge the grants received from Universiti Teknologi PETRONAS under YUTP and UTP-UIR with cost centers 015LCO-211 and 015MEO-166 respectively. We also wish to acknowledge King Khalid University, Abha, Kingdom of Saudi Arabia.

Conflicts of Interest: The authors declare no conflict of interest.

\section{References}

1. Oh, J.Y.; Choi, S.D.; Kwon, H.O.; Lee, S.E. Leaching of polycyclic aromatic hydrocarbons (PAHs) from industrial wastewater sludge by ultrasonic treatment. Ultrason. Sonochem. 2016, 33, 61-66. [CrossRef] [PubMed]

2. Zhang, Y.; Zhang, L.; Huang, Z.; Li, Y.; Li, J.; Wu, N.; He, J.; Zhang, Z.; Liu, Y.; Niu, Z. Pollution of polycyclic aromatic hydrocarbons (PAHs) in drinking water of China: Composition, distribution and influencing factors. Ecotoxicol. Environ. Saf. 2019, 177, 108-116. [CrossRef] [PubMed]

3. Tian, W.; Bai, J.; Liu, K.; Sun, H.; Zhao, Y. Occurrence and removal of polycyclic aromatic hydrocarbons in the wastewater treatment process. Ecotoxicol. Environ. Saf. 2012, 82, 1-7. [CrossRef] [PubMed]

4. Crisafully, R.; Milhome, M.A.L.; Cavalcante, R.M.; Silveira, E.R.; De Keukeleire, D.; Nascimento, R.F. Removal of some polycyclic aromatic hydrocarbons from petrochemical wastewater using low-cost adsorbents of natural origin. Bioresour. Technol. 2008, 99, 4515-4519. [CrossRef]

5. Zhang, Y.; Tao, S. Global atmospheric emission inventory of polycyclic aromatic hydrocarbons (PAHs) for 2004. Atmos. Environ. 2009, 43, 812-819. [CrossRef]

6. Liu, Y.; Zarfl, C.; Basu, N.B.; Cirpka, O.A. Turnover and legacy of sediment-associated PAH in a baseflow-dominated river. Sci. Total Environ. 2019, 671, 754-764. [CrossRef]

7. Andrade, M.V.F.; Santos, F.R.; Oliveira, A.H.B.; Nascimento, R.F.; Cavalcante, R.M. Influence of sediment parameters on the distribution and fate of PAHs in an estuarine tropical region located in the Brazilian semi-arid (Jaguaribe River, Ceará coast). Mar. Pollut. Bull. 2019, 146, 703-710. [CrossRef]

8. Zhao, W.; Sui, Q.; Huang, X. Removal and fate of polycyclic aromatic hydrocarbons in a hybrid anaerobic-anoxic-oxic process for highly toxic coke wastewater treatment. Sci. Total Environ. 2018, 635, 716-724. [CrossRef]

9. Sun, S.; Jia, L.; Li, B.; Yuan, A.; Kong, L.; Qi, H.; Ma, W.; Zhang, A.; Wu, Y. The occurrence and fate of PAHs over multiple years in a wastewater treatment plant of Harbin, Northeast China. Sci. Total Environ. 2018, 624, 491-498. [CrossRef]

10. De Gisi, S.; Lofrano, G.; Grassi, M.; Notarnicola, M. Characteristics and adsorption capacities of low-cost sorbents for wastewater treatment: A review. Sustain. Mater. Technol. 2016, 9, 10-40. [CrossRef]

11. Qiao, M.; Qi, W.; Liu, H.; Qu, J. Oxygenated, nitrated, methyl and parent polycyclic aromatic hydrocarbons in rivers of Haihe River System, China: Occurrence, possible formation, and source and fate in a water-shortage area. Sci. Total Environ. 2014, 481, 178-185. [CrossRef] [PubMed]

12. Zango, Z.U.; Garba, Z.N.; Abu Bakar, N.H.H.; Tan, W.L.; Abu Bakar, M. Adsorption studies of Cu ${ }^{2+}-\mathrm{Hal}$ nanocomposites for the removal of 2,4,6-trichlorophenol. Appl. Clay Sci. 2016, 132-133, 68-78. [CrossRef]

13. Lawal, I.A.; Lawal, M.M.; Azeez, M.A.; Ndungu, P. Theoretical and experimental adsorption studies of phenol and crystal violet dye on carbon nanotube functionalized with deep eutectic solvent. J. Mol. Liq. 2019, 288. [CrossRef] 
14. Catherine, H.N.; Ou, M.H.; Manu, B.; Shih, Y. hsin Adsorption mechanism of emerging and conventional phenolic compounds on graphene oxide nanoflakes in water. Sci. Total Environ. 2018, 635, 629-638. [CrossRef] [PubMed]

15. Bazrafshan, E.; Mostafapour, F.K.; Mahvi, A.H. Phenol removal from aqueous solutions using pistachio-nut shell ash as a low cost adsorbent. Fresenius Environ. Bull. 2012, 21, 2962-2968.

16. Soni, U.; Bajpai, J.; Singh, S.K.; Bajpai, A.K. Evaluation of chitosan-carbon based biocomposite for efficient removal of phenols from aqueous solutions. J. Water Process Eng. 2017, 16, 56-63. [CrossRef]

17. Guo, M.; Wang, J.; Wang, C.; Strong, P.J.; Jiang, P.; Ok, Y.S.; Wang, H. Carbon nanotube-grafted chitosan and its adsorption capacity for phenol in aqueous solution. Sci. Total Environ. 2019, 682, 340-347. [CrossRef]

18. Zhang, Y.; Qin, L.; Cui, Y.; Liu, W.; Liu, X.; Yang, Y. A hydrophilic surface molecularly imprinted polymer on a spherical porous carbon support for selective phenol removal from coking wastewater. New Carbon Mater. 2020, 35, 220-231. [CrossRef]

19. Salari, M.; Dehghani, M.H.; Azari, A.; Motevalli, M.D.; Shabanloo, A.; Ali, I. High performance removal of phenol from aqueous solution by magnetic chitosan based on response surface methodology and genetic algorithm. J. Mol. Liq. 2019, 285, 146-157. [CrossRef]

20. Lee, C.G.; Hong, S.H.; Hong, S.G.; Choi, J.W.; Park, S.J. Production of Biochar from Food Waste and its Application for Phenol Removal from Aqueous Solution. Water Air Soil Pollut. 2019, 230. [CrossRef]

21. Wang, F.; Haftka, J.J.H.; Sinnige, T.L.; Hermens, J.L.M.; Chen, W. Adsorption of polar, nonpolar, and substituted aromatics to colloidal graphene oxide nanoparticles. Environ. Pollut. 2014, 186, 226-233. [CrossRef]

22. Zhou, L.C.; Meng, X.G.; Fu, J.W.; Yang, Y.C.; Yang, P.; Mi, C. Highly efficient adsorption of chlorophenols onto chemically modified chitosan. Appl. Surf. Sci. 2014, 292, 735-741. [CrossRef]

23. Blanchard, M.; Teil, M.J.; Ollivon, D.; Legenti, L.; Chevreuil, M. Polycyclic aromatic hydrocarbons and polychlorobiphenyls in wastewaters and sewage sludges from the Paris area (France). Environ. Res. 2004, 95, 184-197. [CrossRef] [PubMed]

24. Mojiri, A.; Zhou, J.L.; Ohashi, A.; Ozaki, N.; Kindaichi, T. Comprehensive review of polycyclic aromatic hydrocarbons in water sources, their effects and treatments. Sci. Total Environ. 2019, 696. [CrossRef] [PubMed]

25. Lamichhane, S.; Bal Krishna, K.C.; Sarukkalige, R. Polycyclic aromatic hydrocarbons (PAHs) removal by sorption: A review. Chemosphere 2016, 148, 336-353. [CrossRef] [PubMed]

26. Alegbeleye, O.O.; Opeolu, B.O.; Jackson, V.A. Polycyclic Aromatic Hydrocarbons: A Critical Review of Environmental Occurrence and Bioremediation. Environ. Manag. 2017, 60, 758-783. [CrossRef]

27. Ndunda, E.N.; Mizaikoff, B. Molecularly imprinted polymers for the analysis and removal of polychlorinated aromatic compounds in the environment: A review. Analyst 2016, 141, 3141-3156. [CrossRef]

28. Kumar, V.; Kim, K.H.; Park, J.W.; Hong, J.; Kumar, S. Graphene and its nanocomposites as a platform for environmental applications. Chem. Eng. J. 2017, 315, 210-232. [CrossRef]

29. de Souza, C.V.; Corrêa, S.M. Polycyclic aromatic hydrocarbons in diesel emission, diesel fuel and lubricant oil. Fuel 2016, 185, 925-931. [CrossRef]

30. Akinpelu, A.A.; Ali, M.E.; Johan, M.R.; Saidur, R.; Qurban, M.A.; Saleh, T.A. Polycyclic aromatic hydrocarbons extraction and removal from wastewater by carbon nanotubes: A review of the current technologies, challenges and prospects. Process Saf. Environ. Prot. 2019, 122, 68-82. [CrossRef]

31. Redondo, J.M.; Platonov, A.K. Self-similar distribution of oil spills in European coastal waters. Environ. Res. Lett. 2009, 4. [CrossRef]

32. Lai, X.; Ning, X.-A.; He, Y.; Yuan, Y.; Sun, J.; Ke, Y.; Man, X. Treatment of a simulated sludge by ultrasonic zero-valent iron/EDTA/Air process: Interferences of inorganic salts in polyaromatic hydrocarbon removal. Waste Manag. 2019, 85, 548-556. [CrossRef] [PubMed]

33. Lu, Y.; Zheng, G.; Zhou, W.; Wang, J.; Zhou, L. Bioleaching conditioning increased the bioavailability of polycyclic aromatic hydrocarbons to promote their removal during co-composting of industrial and municipal sewage sludges. Sci. Total Environ. 2019, 665, 1073-1082. [CrossRef]

34. Ihsanullah; Asmaly, H.A.; Saleh, T.A.; Laoui, T.; Gupta, V.K.; Atieh, M.A. Enhanced adsorption of phenols from liquids by aluminum oxide/carbon nanotubes: Comprehensive study from synthesis to surface properties. J. Mol. Liq. 2015, 206, 176-182. [CrossRef]

35. Marañón, E.; Vázquez, I.; Rodríguez, J.; Castrillón, L.; Fernández, Y.; López, H. Treatment of coke wastewater in a sequential batch reactor (SBR) at pilot plant scale. Bioresour. Technol. 2008, 99, 4192-4198. [CrossRef] 
36. Bargiel, P.; Zabochnicka-Światek, M. Technologies of Coke Wastewater Treatment in the Frame of Legislation in Force. Ochr. Sr. Zasobow Nat. 2018, 29, 11-15. [CrossRef]

37. Pal, P.; Kumar, R. Treatment of coke wastewater: A critical review for developing sustainable management strategies. Sep. Purif. Rev. 2014, 43, 89-123. [CrossRef]

38. Ning, X.A.; Lin, M.Q.; Shen, L.Z.; Zhang, J.H.; Wang, J.Y.; Wang, Y.J.; Yang, Z.Y.; Liu, J.Y. Levels, composition profiles and risk assessment of polycyclic aromatic hydrocarbons (PAHs) in sludge from ten textile dyeing plants. Environ. Res. 2014, 132, 112-118. [CrossRef]

39. Anku, W.W.; Mamo, M.A.; Govender, P.P. Phenolic Compounds in Water: Sources, Reactivity, Toxicity and Treatment Methods. Intech Open 2016, 419-443. [CrossRef]

40. Agarwal, T.; Khillare, P.S.; Shridhar, V. PAHs contamination in Bank sediment of the Yamuna River, Delhi, India. Environ. Monit. Assess. 2006, 123, 151-166. [CrossRef]

41. Iwegbue, C.M.A.; Tesi, G.O.; Overah, L.C.; Emoyan, O.O.; Nwajei, G.E.; Martincigh, B.S. Effects of Flooding on the Sources, Spatiotemporal Characteristics and Human Health Risks of Polycyclic Aromatic Hydrocarbons in Floodplain Soils of the Lower Parts of the River Niger, Nigeria. Polycycl. Aromat. Compd. 2017, 6638, 1-17. [CrossRef]

42. Ciesielczuk, T.; Kusza, G.; Poluszyńska, J.; Kochanowska, K. Pollution of flooded arable soils with heavy metals and polycyclic aromatic hydrocarbons (PAHs). Water Air Soil Pollut. 2014, 225. [CrossRef] [PubMed]

43. Liu, J.J.; Wang, X.C.; Fan, B. Characteristics of PAHs adsorption on inorganic particles and activated sludge in domestic wastewater treatment. Bioresour. Technol. 2011, 102, 5305-5311. [CrossRef] [PubMed]

44. Jin, J.; Wang, S.; Hu, J.; Wu, J.; Li, M.; Wang, Y.; Jin, J. Polychlorinated naphthalenes in human serum samples from an industrial city in Eastern China: Levels, sources, and sex differences. Ecotoxicol. Environ. Saf. 2019, 177, 86-92. [CrossRef]

45. Liang, X.; Junaid, M.; Wang, Z.; Li, T.; Xu, N. Spatiotemporal distribution, source apportionment and ecological risk assessment of PBDEs and PAHs in the Guanlan River from rapidly urbanizing areas of Shenzhen, China. Environ. Pollut. 2019, 250, 695-707. [CrossRef] [PubMed]

46. McDonough, C.A.; Khairy, M.A.; Muir, D.C.G.; Lohmann, R. Significance of population centers as sources of gaseous and dissolved PAHs in the lower Great Lakes. Environ. Sci. Technol. 2014, 48, 7789-7797. [CrossRef] [PubMed]

47. Zhang, W.; Wei, C.; Chai, X.; He, J.; Cai, Y.; Ren, M.; Yan, B.; Peng, P.; Fu, J. The behaviors and fate of polycyclic aromatic hydrocarbons (PAHs) in a coking wastewater treatment plant. Chemosphere 2012, 88, 174-182. [CrossRef]

48. Li, J.; Dong, H.; Xu, X.; Han, B.; Li, X.; Zhu, C.; Han, C.; Liu, S.; Yang, D.; Xu, Q.; et al. Prediction of the bioaccumulation of PAHs in surface sediments of Bohai Sea, China and quantitative assessment of the related toxicity and health risk to humans. Mar. Pollut. Bull. 2016, 104, 92-100. [CrossRef]

49. de Jesus, J.H.F.; Cunha, G.d.C.; Cardoso, E.M.C.; Mangrich, A.S.; Romão, L.P.C. Evaluation of waste biomasses and their biochars for removal of polycyclic aromatic hydrocarbons. J. Environ. Manag. 2017, 200, 186-195. [CrossRef]

50. Qu, Y.; Qin, L.; Liu, X.; Yang, Y. Reasonable design and sifting of microporous carbon nanosphere-based surface molecularly imprinted polymer for selective removal of phenol from wastewater. Chemosphere 2020, 251. [CrossRef]

51. Wu, Z.; Yuan, X.; Zhong, H.; Wang, H.; Zeng, G.; Chen, X.; Wang, H.; Zhang, L.; Shao, J. Enhanced adsorptive removal of $\mathrm{p}$-nitrophenol from water by aluminum metal-organic framework/reduced graphene oxide composite. Sci. Rep. 2016, 6, 25638. [CrossRef] [PubMed]

52. Kong, Q.; Wu, H.; Liu, L.; Zhang, F.; Preis, S.; Zhu, S.; Wei, C. Solubilization of polycyclic aromatic hydrocarbons (PAHs) with phenol in coking wastewater treatment system: Interaction and engineering significance. Sci. Total Environ. 2018, 628-629, 467-473. [CrossRef]

53. Villegas, L.G.C.; Mashhadi, N.; Chen, M.; Mukherjee, D.; Taylor, K.E.; Biswas, N. A Short Review of Techniques for Phenol Removal from Wastewater. Curr. Pollut. Rep. 2016, 2, 157-167. [CrossRef]

54. Bin-Dahman, O.A.; Saleh, T.A. Synthesis of carbon nanotubes grafted with PEG and its efficiency for the removal of phenol from industrial wastewater. Environ. Nanotechnol. Monit. Manag. 2020, 13. [CrossRef]

55. Saleh, T.A.; Elsharif, A.M.; Asiri, S.; Mohammed, A.R.I.; Dafalla, H. Synthesis of carbon nanotubes grafted with copolymer of acrylic acid and acrylamide for phenol removal. Environ. Nanotechnol. Monit. Manag. 2020, 14. [CrossRef] 
56. Godlewska, P.; Siatecka, A.; Kończak, M.; Oleszczuk, P. Adsorption capacity of phenanthrene and pyrene to engineered carbon-based adsorbents produced from sewage sludge or sewage sludge-biomass mixture in various gaseous conditions. Bioresour. Technol. 2019, 280, 421-429. [CrossRef] [PubMed]

57. Giwa, A.; Daer, S.; Ahmed, I.; Marpu, P.R.; Hasan, S.W. Experimental investigation and artificial neural networks ANNs modeling of electrically-enhanced membrane bioreactor for wastewater treatment. J. Water Process Eng. 2016, 11, 88-97. [CrossRef]

58. Lin, M.; Ning, X.-a.; An, T.; Zhang, J.; Chen, C.; Ke, Y.; Wang, Y.; Zhang, Y.; Sun, J.; Liu, J. Degradation of polycyclic aromatic hydrocarbons (PAHs) in textile dyeing sludge with ultrasound and Fenton processes: Effect of system parameters and synergistic effect study. J. Hazard. Mater. 2016, 307, 7-16. [CrossRef]

59. Bai, H.; Zhou, J.; Zhang, H.; Tang, G. Enhanced adsorbability and photocatalytic activity of $\mathrm{TiO}_{2}$-graphene composite for polycyclic aromatic hydrocarbons removal in aqueous phase. Colloids Surf. B Biointerfaces 2017, 150, 68-77. [CrossRef]

60. Huang, D.; Xu, B.; Wu, J.; Brookes, P.C.; Xu, J. Adsorption and desorption of phenanthrene by magnetic graphene nanomaterials from water: Roles of $\mathrm{pH}$, heavy metal ions and natural organic matter. Chem. Eng. J. 2019, 368, 390-399. [CrossRef]

61. Hwang, H.; Sahin, O.; Choi, J.W. Manufacturing a super-active carbon using fast pyrolysis char from biomass and correlation study on structural features and phenol adsorption. RSC Adv. 2017, 7, 42192-42202. [CrossRef]

62. $\mathrm{Xu}, \mathrm{J} . ;$ Wang, L.; Zhu, Y. Decontamination of bisphenol A from aqueous solution by graphene adsorption. Langmuir 2012, 28, 8418-8425. [CrossRef] [PubMed]

63. Wang, J.; Chen, Z.; Chen, B. Adsorption of polycyclic aromatic hydrocarbons by graphene and graphene oxide nanosheets. Environ. Sci. Technol. 2014, 48, 4817-4825. [CrossRef] [PubMed]

64. Yang, X.; Li, J.; Wen, T.; Ren, X.; Huang, Y.; Wang, X. Adsorption of naphthalene and its derivatives on magnetic graphene composites and the mechanism investigation. Colloids Surf. A Physicochem. Eng. Asp. 2013, 422, 118-125. [CrossRef]

65. Mohammad, A.T.; Al-Obaidi, M.A.; Hameed, E.M.; Basheer, B.N.; Mujtaba, I.M. Modelling the chlorophenol removal from wastewater via reverse osmosis process using a multilayer artificial neural network with genetic algorithm. J. Water Process Eng. 2020, 33. [CrossRef]

66. Yakout, S.M.; Daifullah, A.A.M.; El-Refeey, S.A. Adsorption of Naphthalene, Phenanthrene and Pyrene from Aqueous Solution Using Low-Cost Activated Carbon Derived from Agricultural. Adsorpt. Sci. Technol. 2013, 31, 293-302. [CrossRef]

67. Gundogdu, A.; Duran, C.; Senturk, H.B.; Soylak, M.; Ozdes, D.; Serencam, H.; Imamoglu, M. Adsorption of phenol from aqueous solution on a low-cost activated carbon produced from tea industry waste: Equilibrium, kinetic, and thermodynamic study. J. Chem. Eng. Data 2012, 57, 2733-2743. [CrossRef]

68. Rasheed, A.; Farooq, F.; Rafique, U.; Nasreen, S.; Aqeel Ashraf, M. Analysis of sorption efficiency of activated carbon for removal of anthracene and pyrene for wastewater treatment. Desalin. Water Treat. 2016, 57, 145-150. [CrossRef]

69. Feng, Z.; Zhu, L. Sorption of phenanthrene to biochar modified by base. Front. Environ. Sci. Eng. 2018, 12, 1-11. [CrossRef]

70. Tong, Y.; McNamara, P.J.; Mayer, B.K. Adsorption of organic micropollutants onto biochar: A review of relevant kinetics, mechanisms and equilibrium. Environ. Sci. Water Res. Technol. 2019, 5, 821-838. [CrossRef]

71. Xu, L.; Wang, Z.; Ye, S.; Sui, X. Removal of p-chlorophenol from aqueous solutions by carbon nanotube hybrid polymer adsorbents. Chem. Eng. Res. Des. 2017, 123, 76-83. [CrossRef]

72. Zhang, J.; Li, R.; Ding, G.; Wang, Y.; Wang, C. Sorptive removal of phenanthrene from water by magnetic carbon nanomaterials. J. Mol. Liq. 2019, 293. [CrossRef]

73. Zielińska, A.; Oleszczuk, P. The conversion of sewage sludge into biochar reduces polycyclic aromatic hydrocarbon content and ecotoxicity but increases trace metal content. Biomass Bioenergy 2015, 75, 235-244. [CrossRef]

74. Smith, K.M.; Fowler, G.D.; Pullket, S.; Graham, N.J.D. Sewage sludge-based adsorbents: A review of their production, properties and use in water treatment applications. Water Res. 2009, 43, 2569-2594. [CrossRef] 
75. Azargohar, R.; Jacobson, K.L.; Powell, E.E.; Dalai, A.K. Evaluation of properties of fast pyrolysis products obtained, from Canadian waste biomass. J. Anal. Appl. Pyrolysis 2013, 104, 330-340. [CrossRef]

76. Qiu, M.; Sun, K.; Jin, J.; Gao, B.; Yan, Y.; Han, L.; Wu, F.; Xing, B. Properties of the plant- and manure-derived biochars and their sorption of dibutyl phthalate and phenanthrene. Sci. Rep. 2014, 4, 5295. [CrossRef]

77. Askeland, M.; Clarke, B.; Paz-Ferreiro, J. Comparative characterization of biochars produced at three selected pyrolysis temperatures from common woody and herbaceous waste streams. PeerJ 2019, 7, e6784. [CrossRef]

78. Guo, W.; Wang, S.; Wang, Y.; Lu, S.; Gao, Y. Sorptive removal of phenanthrene from aqueous solutions using magnetic and non-magnetic rice husk-derived biochars. R. Soc. Open Sci. 2018, 5, 1-11. [CrossRef] [PubMed]

79. Li, H.; Qu, R.; Li, C.; Guo, W.; Han, X.; He, F.; Ma, Y.; Xing, B. Selective removal of polycyclic aromatic hydrocarbons (PAHs) from soil washing effluents using biochars produced at different pyrolytic temperatures. Bioresour. Technol. 2014, 163, 193-198. [CrossRef]

80. Md Arshad, S.H.; Ngadi, N.; Wong, S.; Saidina Amin, N.; Razmi, F.A.; Mohamed, N.B.; Inuwa, I.M.; Abdul Aziz, A. Optimization of phenol adsorption onto biochar from oil palm empty fruit bunch (EFB). Malays. J. Fundam. Appl. Sci. 2019, 15,1-5. [CrossRef]

81. Bedia, J.; Peñas-Garzón, M.; Gómez-Avilés, A.; Rodriguez, J.; Belver, C. A Review on the Synthesis and Characterization of Biomass-Derived Carbons for Adsorption of Emerging Contaminants from Water. J. Carbon Res. 2018, 4, 63. [CrossRef]

82. Qiao, K.; Tian, W.; Bai, J.; Dong, J.; Zhao, J.; Gong, X.; Liu, S. Preparation of biochar from Enteromorpha prolifera and its use for the removal of polycyclic aromatic hydrocarbons (PAHs) from aqueous solution. Ecotoxicol. Environ. Saf. 2018, 149, 80-87. [CrossRef]

83. Tang, J.; Lv, H.; Gong, Y.; Huang, Y. Preparation and characterization of a novel graphene/biochar composite for aqueous phenanthrene and mercury removal. Bioresour. Technol. 2015, 196, 355-363. [CrossRef] [PubMed]

84. de Jesus, J.H.F.; Matos, T.T.d.S.; Cunha, G.d.C.; Mangrich, A.S.; Romão, L.P.C. Adsorption of aromatic compounds by biochar: Influence of the type of tropical biomass precursor. Cellulose 2019. [CrossRef]

85. Liu, X.; Sun, J.; Duan, S.; Wang, Y.; Hayat, T.; Alsaedi, A.; Wang, C.; Li, J. A Valuable Biochar from Poplar Catkins with High Adsorption Capacity for Both Organic Pollutants and Inorganic Heavy Metal Ions. Sci. Rep. 2017, 7, 10033. [CrossRef]

86. Shin, W. seok Adsorption characteristics of phenol and heavy metals on biochar from Hizikia fusiformis. Environ. Earth Sci. 2017, 76, 782. [CrossRef]

87. Braghiroli, F.L.; Bouafif, H.; Hamza, N.; Neculita, C.M.; Koubaa, A. Production, characterization, and potential of activated biochar as adsorbent for phenolic compounds from leachates in a lumber industry site. Environ. Sci. Pollut. Res. 2018, 25, 26562-26575. [CrossRef]

88. Zhang, Y.; Tang, Z.; Liu, S.; Xu, H.; Song, Z. Study on adsorption of phenol from aqueous media using biochar of Chinese herb residue. IOP Conf. Ser. Mater. Sci. Eng. 2018, 394. [CrossRef]

89. Siipola, V.; Pflugmacher, S.; Romar, H.; Wendling, L.; Koukkari, P. Low-Cost Biochar Adsorbents for Water Purification Including Microplastics Removal. Appl. Sci. 2020, 10, 788. [CrossRef]

90. Jin, D.F.; Xu, Y.Y.; Zhang, M.; Jung, Y.S.; Ok, Y.S. Comparative evaluation for the sorption capacity of four carbonaceous sorbents to phenol. Chem. Speciat. Bioavailab. 2016, 28, 18-25. [CrossRef]

91. Mohammed, N.A.S.; Abu-Zurayk, R.A.; Hamadneh, I.; Al-Dujaili, A.H. Phenol adsorption on biochar prepared from the pine fruit shells: Equilibrium, kinetic and thermodynamics studies. J. Environ. Manag. 2018, 226, 377-385. [CrossRef] [PubMed]

92. Danish, M.; Ahmad, T. A review on utilization of wood biomass as a sustainable precursor for activated carbon production and application. Renew. Sustain. Energy Rev. 2018, 87, 1-21. [CrossRef]

93. Alade, A.O.; Amuda, O.S.; Ibrahim, A.O. Isothermal studies of adsorption of acenaphthene from aqueous solution onto activated carbon produced from rice (Oryza sativa) husk. Elixir Chem. Eng. 2012, 46, 87-95. [CrossRef]

94. Alade, A.O.; Amuda, O.S.; Afolabi, T.J.; Okoya, A.A. Adsorption of naphthalene onto activated carbons derived from milk bush kernel shell and flamboyant pod. J. Environ. Chem. Ecotoxicol. 2012, 4, 124-132. [CrossRef]

95. Jin, X.J.; Zhu, Y.M. Absorption of Phenol on Nitrogen-Enriched Activated Carbon from Wood Fiberboard Waste with Chemical Activation by Potassium Carbonate. J. Chem. Eng. Process Technol. 2014, 5, 4. [CrossRef]

96. Ingole, R.S.; Lataye, D.H. Adsorptive removal of phenol from aqueous solution using activated carbon prepared from Babul sawdust. J. Hazard. Toxicol. Radioact. Waste 2015, 19, 1-9. [CrossRef] 
97. Dąbrowski, A.; Podkościelny, P.; Hubicki, Z.; Barczak, M. Adsorption of phenolic compounds by activated carbon-A critical review. Chemosphere 2005, 58, 1049-1070. [CrossRef]

98. Xiao, X.; Liu, D.; Yan, Y.; Wu, Z.; Wu, Z.; Cravotto, G. Preparation of activated carbon from Xinjiang region coal by microwave activation and its application in naphthalene, phenanthrene, and pyrene adsorption. J. Taiwan Inst. Chem. Eng. 2015, 53, 160-167. [CrossRef]

99. Eeshwarasinghe, D.; Loganathan, P.; Vigneswaran, S. Simultaneous removal of polycyclic aromatic hydrocarbons and heavy metals from water using granular activated carbon. Chemosphere 2019, 223, 616-627. [CrossRef]

100. Rakowska, M.I.; Kupryianchyk, D.; Grotenhuis, T.; Rijnaarts, H.H.M.; Koelmans, A.A. Extraction of sediment-associated polycyclic aromatic hydrocarbons with granular activated carbon. Environ. Toxicol. Chem. 2013, 32, 304-311. [CrossRef]

101. Ge, X.; Wu, Z.; Wu, Z.; Yan, Y.; Cravotto, G.; Ye, B.C. Enhanced PAHs adsorption using iron-modified coal-based activated carbon via microwave radiation. J. Taiwan Inst. Chem. Eng. 2016, 64, 235-243. [CrossRef]

102. Ge, X.; Tian, F.; Wu, Z.; Yan, Y.; Cravotto, G.; Wu, Z. Adsorption of naphthalene from aqueous solution on coal-based activated carbon modi fi ed by microwave induction: Microwave power effects. Chem. Eng. Process. 2015, 91, 67-77. [CrossRef]

103. Wu, Z.; Sun, Z.; Liu, P.; Li, Q.; Yang, R.; Yang, X. Competitive adsorption of naphthalene and phenanthrene on walnut shell based activated carbon and the veri fi cation via theoretical. RSC Adv. 2020, 10, 10703-10714. [CrossRef]

104. Liu, J.; Chen, J.; Jiang, L.; Yin, X. Adsorption of mixed polycyclic aromatic hydrocarbons in surfactant solutions by activated carbon. J. Ind. Eng. Chem. 2014, 20, 616-623. [CrossRef]

105. Alade, A.O.; Amuda, O.S.; Afolabi, A.O.; Adelowo, F.E. Adosrption of Acenaphthene unto Ativated Crabon Produced from Agricultural Wastes. J. Envion. Sci. Technol. 2012, 5, 192-209.

106. Yakout, S.M.; Daifullah, A.A.M.; El-Reefy, S.A. Equilibrium and kinetic studies of sorption of polycyclic aromatic hydrocarbons from water using rice husk activated carbon. Asian J. Chem. 2013, 25, 10037-10042. [CrossRef]

107. Rinawati; Hidayat, D.; Supriyanto, R.; Permana, D.F. Yunita Adsorption of Polycyclic Aromatic Hydrocarbons using Low-Cost Activated Carbon Derived from Rice Husk. J. Phys. Conf. Ser. 2019, 1338. [CrossRef]

108. Awe, A.A.; Opeolu, B.O.; Fatoki, O.S.; Ayanda, O.S.; Jackson, V.A.; Snyman, R. Preparation and characterisation of activated carbon from Vitis vinifera leaf litter and its adsorption performance for aqueous phenanthrene. Appl. Biol. Chem. 2020, 63, 12. [CrossRef]

109. Khare, P.; Kumar, A. Removal of phenol from aqueous solution using carbonized Terminalia chebula-activated carbon: Process parametric optimization using conventional method and Taguchi's experimental design, adsorption kinetic, equilibrium and thermodynamic study. Appl. Water Sci. 2012, 2, 317-326. [CrossRef]

110. Lin, J.Q.; Yang, S.E.; Duan, J.M.; Wu, J.J.; Jin, L.Y.; Lin, J.M.; Deng, Q.L. The Adsorption Mechanism of Modified Activated Carbon on Phenol. MATEC Web Conf. 2016, 67. [CrossRef]

111. Biglari, H.; Afsharnia, M.; Javan, N.; Sajadi, S.A. Phenol Removal from Aqueous Solutions by Adsorption on Activated Carbon of Miswak's Root Treated with KMnO4. Iran. J. Health Sci. 2016, 42, 20-30. [CrossRef]

112. Xie, B.; Qin, J.; Wang, S.; Li, X.; Sun, H.; Chen, W. Adsorption of Phenol on Commercial Activated Carbons: Modelling and Interpretation. Int. J. Environ. Res. Public Health 2020, 17, 789. [CrossRef]

113. Beker, U.; Ganbold, B.; Dertli, H.; Gülbayir, D.D. Adsorption of phenol by activated carbon: Influence of activation methods and solution pH. Energy Convers. Manag. 2010, 51, 235-240. [CrossRef]

114. Germain, T.; Lynda, E.; Tchirioua, E. Adsorption of Phenol on Carbon Based on Cactus and Banana Peel. Aust. J. Basic Appl. Sci. 2019, 13, 64-70. [CrossRef]

115. Mojoudi, N.; Mirghaffari, N.; Soleimani, M.; Shariatmadari, H.; Belver, C.; Bedia, J. Phenol adsorption on high microporous activated carbons prepared from oily sludge: Equilibrium, kinetic and thermodynamic studies. Sci. Rep. 2019, 9, 19352. [CrossRef]

116. Nouha, S.; Souad, N.S.; Abdelmottalab, O. Enhanced adsorption of phenol using alkaline modified activated carbon prepared from olive stones. J. Chil. Chem. Soc. 2019, 64, 4352-4359. [CrossRef]

117. Siti Hadjar, M.A.; Astimar, A.A.; Norzita, N.; Noraishah, S.A. Phenol adsorption by activated carbon of different fibre size derived from empty fruit bunches. J. Oil Palm Res. 2012, 24, 1524-1532.

118. Dejene, K.; Siraj, K.; Kitte, S.A. Kinetic and Thermodynamic Study of Phenol Removal from Water Using Activated Carbon Synthesizes from Avocado Kernel Seed. Int. Lett. Nat. Sci. 2016, 54, 42-57. [CrossRef] 
119. Banat, F.; Al-Asheh, S.; Al-Makhadmeh, L. Utilization of raw and activated date pits for the removal of phenol from aqueous solutions. Chem. Eng. Technol. 2004, 27, 80-86. [CrossRef]

120. Mohtashami, S.A.; Asasian Kolur, N.; Kaghazchi, T.; Asadi-Kesheh, R.; Soleimani, M. Optimization of sugarcane bagasse activation to achieve adsorbent with high affinity towards phenol. Turk. J. Chem. 2018, 42, 1720-1735. [CrossRef]

121. Girish, C.R.; Murty, V.R. Adsorption of Phenol from Aqueous Solution Using Lantana camara, Forest Waste: Packed Bed Studies and Prediction of Breakthrough Curves. Environ. Process. 2014, 2, 773-796. [CrossRef]

122. Mohammadi, S.Z.; Darijani, Z.; Karimi, M.A. Fast and efficient removal of phenol by magnetic activated carbon-cobalt nanoparticles. J. Alloys Compd. 2020, 832. [CrossRef]

123. Gholizadeh, A.; Kermani, M.; Gholami, M.; Farzadkia, M. Kinetic and isotherm studies of adsorption and biosorption processes in the removal of phenolic compounds from aqueous solutions: Comparative study. J. Environ. Health Sci. Eng. 2013, 11, 29. [CrossRef] [PubMed]

124. Ioannou, Z.; Simitzis, J. Adsorption kinetics of phenol and 3-nitrophenol from aqueous solutions on conventional and novel carbons. J. Hazard. Mater. 2009, 171, 954-964. [CrossRef] [PubMed]

125. Yadav, N.; Narayan Maddheshiaya, D.; Rawat, S.; Singh, J. Adsorption and equilibrium studies of phenol and para-nitrophenol by magnetic activated carbon synthesised from cauliflower waste. Environ. Eng. Res. 2019, 25, 742-752. [CrossRef]

126. Atieh, M.A. Removal of Phenol from Water Different Types of Carbon-A Comparative Analysis. APCBEE Procedia 2014, 10, 136-141. [CrossRef]

127. Dehghani, M.H.; Mostofi, M.; Alimohammadi, M.; McKay, G.; Yetilmezsoy, K.; Albadarin, A.B.; Heibati, B.; AlGhouti, M.; Mubarak, N.M.; Sahu, J.N. High-performance removal of toxic phenol by single-walled and multi-walled carbon nanotubes: Kinetics, adsorption, mechanism and optimization studies. J. Ind. Eng. Chem. 2016, 35, 63-74. [CrossRef]

128. Rezakazemi, M.; Kurniawan, T.A.; Albadarin, A.B.; Shirazian, S. Molecular modeling investigation on mechanism of phenol removal from aqueous media by single- and multi-walled carbon nanotubes. J. Mol. Liq. 2018, 271, 24-30. [CrossRef]

129. Wang, L.C.; Ni, X.J.; Cao, Y.H.; Cao, G.Q. Adsorption behavior of bisphenol A on CTAB-modified graphite. Appl. Surf. Sci. 2018, 428, 165-170. [CrossRef]

130. Chowdhury, S.; Balasubramanian, R. Recent advances in the use of graphene-family nanoadsorbents for removal of toxic pollutants from wastewater. Adv. Colloid Interface Sci. 2014, 204, 35-56. [CrossRef]

131. Li, B.; Ou, P.; Wei, Y.; Zhang, X.; Song, J. Polycyclic aromatic hydrocarbons adsorption onto graphene: A DFT and AIMD study. Materials 2018, 11, 726. [CrossRef] [PubMed]

132. Fraga, T.J.M.; Carvalho, M.N.; Ghislandi, M.G.; Da Motta Sobrinho, M.A. Functionalized graphene-based materials as innovative adsorbents of organic pollutants: A concise overview. Braz. J. Chem. Eng. 2019, 36, 1-31. [CrossRef]

133. Ali, I.; Basheer, A.A.; Mbianda, X.Y.; Burakov, A.; Galunin, E.; Burakova, I.; Mkrtchyan, E.; Tkachev, A.; Grachev, V. Graphene based adsorbents for remediation of noxious pollutants from wastewater. Environ. Int. 2019, 127, 160-180. [CrossRef]

134. Bano, Z.; Mazari, S.A.; Saeed, R.M.Y.; Majeed, M.A.; Xia, M.; Memon, A.Q.; Abro, R.; Wang, F. Water decontamination by 3D graphene based materials: A review. J. Water Process Eng. 2020, 36, 101404. [CrossRef]

135. Sun, Y.; Yang, S.; Zhao, G.; Wang, Q.; Wang, X. Adsorption of polycyclic aromatic hydrocarbons on graphene oxides and reduced graphene oxides. Chemistry 2013, 8, 2755-2761. [CrossRef]

136. Adeola, A.O.; Forbes, P.B.C. Optimization of the sorption of selected polycyclic aromatic hydrocarbons by regenerable graphene wool. Water Sci. Technol. 2020, 80, 1931-1943. [CrossRef]

137. Zhou, Q.; Wang, Y.; Xiao, J.; Fan, H. Fabrication and characterisation of magnetic graphene oxide incorporated $\mathrm{Fe}_{3} \mathrm{O}_{4} @$ polyaniline for the removal of bisphenol A, t-octyl-phenol, and $\alpha$-naphthol from water. Sci. Rep. 2017, 7, 11316. [CrossRef]

138. Wang, X.; Hu, Y.; Min, J.; Li, S.; Deng, X.; Yuan, S.; Zuo, X. Adsorption characteristics of phenolic compounds on graphene oxide and reduced graphene oxide: A batch experiment combined theory calculation. Appl. Sci. 2018, 8, 1950. [CrossRef] 
139. Tian, J.; Wei, J.; Zhang, H.; Kong, Z.; Zhu, Y.; Qin, Z. Graphene oxide-functionalized dual-scale channels architecture for high-throughput removal of organic pollutants from water. Chem. Eng. J. 2019, 359, 852-862. [CrossRef]

140. Apul, O.G.; Wang, Q.; Zhou, Y.; Karanfil, T. Adsorption of aromatic organic contaminants by graphene nanosheets: Comparison with carbon nanotubes and activated carbon. Water Res. 2013, 47, 1648-1654. [CrossRef]

141. Das, P.; Goswami, S.; Maiti, S. Removal of naphthalene present in synthetic waste water using novel Graphene /Graphene Oxide nano sheet synthesized from rice straw: Comparative analysis, isotherm and kinetics. Front. Nanosci. Nanotechnol. 2016, 2, 38-42. [CrossRef]

142. Zhao, G.; Jiang, L.; He, Y.; Li, J.; Dong, H.; Wang, X.; Hu, W. Sulfonated graphene for persistent aromatic pollutant management. Adv. Mater. 2011, 23, 3959-3963. [CrossRef]

143. Mortazavi, M.; Baghdadi, M.; Seyed Javadi, N.H.; Torabian, A. The black beads produced by simultaneous thermal reducing and chemical bonding of graphene oxide on the surface of amino-functionalized sand particles: Application for PAHs removal from contaminated waters. J. Water Process Eng. 2019, 31, 100798. [CrossRef]

144. Wang, J.; Chen, B. Adsorption and coadsorption of organic pollutants and a heavy metal by graphene oxide and reduced graphene materials. Chem. Eng. J. 2015, 281, 379-388. [CrossRef]

145. Mehrizad, A.; Gharbani, P. Decontamination of 4-chloro-2-nitrophenol from aqueous solution by graphene adsorption: Equilibrium, kinetic, and thermodynamic studies. Pol. J. Environ. Stud. 2014, 23, 2111-2116. [CrossRef]

146. De La Luz-Asunción, M.; Sánchez-Mendieta, V.; Martínez-Hernández, A.L.; Castaño, V.M.; Velasco-Santos, C. Adsorption of phenol from aqueous solutions by carbon nanomaterials of one and two dimensions: Kinetic and equilibrium studies. J. Nanomater. 2015, 2015, 405036. [CrossRef]

147. Gholami-Bonabi, L.; Ziaefar, N.; Sheikhloie, H. Removal of phenol from aqueous solutions by magnetic oxide graphene nanoparticles modified with ionic liquids using the Taguchi optimization approach. Water Sci. Technol. 2020, 81, 228-240. [CrossRef]

148. Li, Y.; Du, Q.; Liu, T.; Sun, J.; Jiao, Y.; Xia, Y.; Xia, L.; Wang, Z.; Zhang, W.; Wang, K.; et al. Equilibrium, kinetic and thermodynamic studies on the adsorption of phenol onto graphene. Mater. Res. Bull. 2012, 47, 1898-1904. [CrossRef]

149. Wang, J.; Gao, X.; Wang, Y.; Gao, C. Novel Graphene Oxide Sponge synthesized by Freeze-Drying Process for the Removal of 2,4,6-Trichlorophenol. RSC Adv. 2014, 4, 57476-57482. [CrossRef]

150. Phatthanakittiphong, T.; Seo, G.T. Characteristic evaluation of graphene oxide for bisphenol a adsorption in aqueous solution. Nanomaterials 2016, 6, 128. [CrossRef]

151. Zhang, Y.; Tang, Y.; Li, S.; Yu, S. Sorption and removal of tetrabromobisphenol A from solution by graphene oxide. Chem. Eng. J. 2013, 222, 94-100. [CrossRef]

152. Soltani, T.; Lee, B.K. Mechanism of highly efficient adsorption of 2-chlorophenol onto ultrasonic graphene materials: Comparison and equilibrium. J. Colloid Interface Sci. 2016, 481, 168-180. [CrossRef] [PubMed]

153. Zhou, L.; Zhang, X.; Chen, Y. Modulated synthesis of zirconium metal-Organic framework UiO-66 with enhanced dichloromethane adsorption capacity. Mater. Lett. 2017, 197, 167-170. [CrossRef]

154. Ong, Y.T.; Ahmad, A.L.; Zein, S.H.S.; Tan, S.H. A review on carbon nanotubes in an environmental protection and green engineering perspective. Braz. J. Chem. Eng. 2010, 27, 227-242. [CrossRef]

155. Sarkar, B.; Mandal, S.; Tsang, Y.F.; Kumar, P.; Kim, K.H.; Ok, Y.S. Designer carbon nanotubes for contaminant removal in water and wastewater: A critical review. Sci. Total Environ. 2018, 612, 561-581. [CrossRef]

156. ALOthman, Z.A.; Wabaidur, S.M. Application of carbon nanotubes in extraction and chromatographic analysis: A review. Arab. J. Chem. 2019, 12, 633-651. [CrossRef]

157. Mallakpour, S.; Khadem, E. Carbon nanotube-metal oxide nanocomposites: Fabrication, properties and applications. Chem. Eng. J. 2016, 302, 344-367. [CrossRef]

158. Krstić, V.; Urošević, T.; Pešovski, B. A review on adsorbents for treatment of water and wastewaters containing copper ions. Chem. Eng. Sci. 2018, 192, 273-287. [CrossRef]

159. Zhang, W.; Zeng, Z.; Liu, Z.; Huang, J.; Xiao, R.; Shao, B.; Liu, Y.; Liu, Y.; Tang, W.; Zeng, G.; et al. Effects of carbon nanotubes on biodegradation of pollutants: Positive or negative? Ecotoxicol. Environ. Saf. 2020, 189. [CrossRef]

160. Yu, J.G.; Zhao, X.H.; Yang, H.; Chen, X.H.; Yang, Q.; Yu, L.Y.; Jiang, J.H.; Chen, X.Q. Aqueous adsorption and removal of organic contaminants by carbon nanotubes. Sci. Total Environ. 2014, 482-483, 241-251. [CrossRef] 
161. Jung, C.; Son, A.; Her, N.; Zoh, K.D.; Cho, J.; Yoon, Y. Removal of endocrine disrupting compounds, pharmaceuticals, and personal care products in water using carbon nanotubes: A review. J. Ind. Eng. Chem. 2015, 27, 1-11. [CrossRef]

162. Saleh, T.A.; Sarı, A.; Tuzen, M. Carbon nanotubes grafted with poly(trimesoyl, m-phenylenediamine) for enhanced removal of phenol. J. Environ. Manag. 2019, 252. [CrossRef]

163. Wu, W.; Yang, K.; Chen, W.; Wang, W.; Zhang, J.; Lin, D.; Xing, B. Correlation and prediction of adsorption capacity and affinity of aromatic compounds on carbon nanotubes. Water Res. 2016, 88, 492-501. [CrossRef]

164. Selvaraj, M.; Hai, A.; Banat, F.; Haija, M.A. Application and prospects of carbon nanostructured materials in water treatment: A review. J. Water Process Eng. 2020, 33. [CrossRef]

165. Apul, O.G.; Karanfil, T. Adsorption of synthetic organic contaminants by carbon nanotubes: A critical review. Water Res. 2015, 68, 34-55. [CrossRef] [PubMed]

166. Ahmad, J.; Naeem, S.; Ahmad, M.; Usman, A.R.A.; Al-Wabel, M.I. A critical review on organic micropollutants contamination in wastewater and removal through carbon nanotubes. J. Environ. Manag. 2019, 246, 214-228. [CrossRef] [PubMed]

167. Yang, K.; Zhu, L.; Xing, B. Adsorption of polycyclic aromatic hydrocarbons by carbon nanomaterials. Environ. Sci. Technol. 2006, 40, 1855-1861. [CrossRef]

168. Kah, M.; Zhang, X.; Jonker, M.T.O.; Hofmann, T. Measuring and modeling adsorption of PAHs to carbon nanotubes over a six order of magnitude wide concentration range. Environ. Sci. Technol. 2011, 45, 6011-6017. [CrossRef]

169. Gotovac, S.; Yang, C.M.; Hattori, Y.; Takahashi, K.; Kanoh, H.; Kaneko, K. Adsorption of polyaromatic hydrocarbons on single wall carbon nanotubes of different functionalities and diameters. J. Colloid Interface Sci. 2007, 314, 18-24. [CrossRef]

170. Pahlavan Yali, Z.; Fatemi, M.H. Prediction of the sorption coefficient for the adsorption of PAHs on MWCNT based on hybrid QSPR-molecular docking approach. Adsorption 2019, 25, 737-743. [CrossRef]

171. Hu, B.; Gao, Z.; Wang, H.; Wang, J.; Cheng, M. Computational insights into the sorption mechanism of polycyclic aromatic hydrocarbons by carbon nanotube through density functional theory calculation and molecular dynamics simulation. Comput. Mater. Sci. 2020, 179. [CrossRef]

172. Kragulj, M.; Tričković, J.; Kukovecz, Á.; Jović, B.; Molnar, J.; Rončević, S.; Kónya, Z.; Dalmacija, B. Adsorption of chlorinated phenols on multiwalled carbon nanotubes. RSC Adv. 2015, 5, 24920-24929. [CrossRef]

173. Yang, K.; Wu, W.; Jing, Q.; Jiang, W.; Xing, B. Competitive adsorption of naphthalene with 2,4-dichlorophenol and 4-chloroaniline on multiwalled carbon nanotubes. Environ. Sci. Technol. 2010, 44, 3021-3027. [CrossRef] [PubMed]

174. Tóth, A.; Törocsik, A.; Tombácz, E.; László, K. Competitive adsorption of phenol and 3-chlorophenol on purified MWCNTs. J. Colloid Interface Sci. 2012, 387, 244-249. [CrossRef]

175. Asmaly, H.A.; Abussaud, B.; Ihsanullah; Saleh, T.A.; Gupta, V.K.; Atieh, M.A. Ferric oxide nanoparticles decorated carbon nanotubes and carbon nanofibers: From synthesis to enhanced removal of phenol. J. Saudi Chem. Soc. 2015, 19, 511-520. [CrossRef]

176. Jiang, L.; Li, S.; Yu, H.; Zou, Z.; Hou, X.; Shen, F.; Li, C.; Yao, X. Amino and thiol modified magnetic multi-walled carbon nanotubes for the simultaneous removal of lead, zinc, and phenol from aqueous solutions. Appl. Surf. Sci. 2016, 369, 398-413. [CrossRef]

177. Alves, D.C.S.; Gonçalves, J.O.; Coseglio, B.B.; Burgo, T.A.L. Adsorption of phenol onto chitosan hydrogel scaffold modified with carbon nanotubes. J. Environ. Chem. Eng. 2019, 7, 103460. [CrossRef]

178. Strachowski, P.; Bystrzejewski, M. Comparative studies of sorption of phenolic compounds onto carbon-encapsulated iron nanoparticles, carbon nanotubes and activated carbon. Colloids Surf. A Physicochem. Eng. Asp. 2015, 467, 113-123. [CrossRef]

179. Yi, L.; Zuo, L.; Wei, C.; Fu, H.; Qu, X.; Zheng, S.; Xu, Z.; Guo, Y.; Li, H.; Zhu, D. Enhanced adsorption of bisphenol A, tylosin, and tetracycline from aqueous solution to nitrogen-doped multiwall carbon nanotubes via cation- $\pi$ and $\pi-\pi$ electron-donor-acceptor (EDA) interactions. Sci. Total Environ. 2020, 719. [CrossRef]

180. Abdel-Ghani, N.T.; El-Chaghaby, G.A.; Helal, F.S. Individual and competitive adsorption of phenol and nickel onto multiwalled carbon nanotubes. J. Adv. Res. 2015, 6, 405-415. [CrossRef]

181. Zhang, Z.; Sun, D.; Li, G.; Zhang, B.; Zhang, B.; Qiu, S.; Li, Y.; Wu, T. Calcined products of Mg-Al layered double hydroxides/single-walled carbon nanotubes nanocomposites for expeditious removal of phenol 
and 4-chlorophenol from aqueous solutions. Colloids Surf. A Physicochem. Eng. Asp. 2019, 565, 143-153. [CrossRef]

182. Chen, G.C.; Shan, X.Q.; Wang, Y.S.; Wen, B.; Pei, Z.G.; Xie, Y.N.; Liu, T.; Pignatello, J.J. Adsorption of 2,4,6-trichlorophenol by multi-walled carbon nanotubes as affected by Cu(II). Water Res. 2009, 43, 2409-2418. [CrossRef] [PubMed]

183. Fathy, M.; Selim, H.; Shahawy, A.E.L. Chitosan/MCM-48 nanocomposite as a potential adsorbent for removing phenol from aqueous solution. RSC Adv. 2020, 10, 23417-23430. [CrossRef]

184. Albayati, T.M.; Kalash, K.R. Polycyclic aromatic hydrocarbons adsorption from wastewater using different types of prepared mesoporous materials MCM-41in batch and fixed bed column. Process Saf. Environ. Prot. 2020, 133, 124-136. [CrossRef]

185. Connolly, B.M.; Mehta, J.P.; Moghadam, P.Z.; Wheatley, A.E.H.; Fairen-Jimenez, D. From synthesis to applications: Metal-organic frameworks for an environmentally sustainable future. Curr. Opin. Green Sustain. Chem. 2018, 12, 47-56. [CrossRef]

186. Jiang, N.; Shang, R.; Heijman, S.G.J.; Rietveld, L.C. High-silica zeolites for adsorption of organic micro-pollutants in water treatment: A review. Water Res. 2018, 144, 145-161. [CrossRef]

187. Wen, Y.; Zhang, J.; Xu, Q.; Wu, X.; Zhu, Q. Pore surface engineering of metal-Organic frameworks for heterogeneous catalysis. Coord. Chem. Rev. 2018, 376, 248-276. [CrossRef]

188. Zhang, Z.; Hou, X.; Zhang, X.; Li, H. The synergistic adsorption of pyrene and copper onto Fe(III) functionalized mesoporous silica from aqueous solution. Colloids Surf. A Physicochem. Eng. Asp. 2017, 520, 39-45. [CrossRef]

189. Nadar, S.S.; Varadan, N.; Suresh, S.; Rao, P.; Ahirrao, D.J.; Adsare, S. Recent progress in nanostructured magnetic framework composites (MFCs): Synthesis and applications. J. Taiwan Inst. Chem. Eng. 2018, 91, 653-677. [CrossRef]

190. Bhatnagar, A.; Anastopoulos, I. Adsorptive removal of bisphenol A (BPA) from aqueous solution: A review. Chemosphere 2017, 168, 885-902. [CrossRef]

191. Mahmodi, G.; Zarrintaj, P.; Taghizadeh, A.; Taghizadeh, M.; Manouchehri, S.; Dangwal, S.; Ronte, A.; Ganjali, M.R.; Ramsey, J.D.; Kim, S.J.; et al. From microporous to mesoporous mineral frameworks: An alliance between zeolite and chitosan. Carbohydr. Res. 2020, 489. [CrossRef] [PubMed]

192. Ahmed, M.J.; Hameed, B.H.; Hummadi, E.H. Review on recent progress in chitosan/chitin-carbonaceous material composites for the adsorption of water pollutants. Carbohydr. Polym. 2020, 247. [CrossRef] [PubMed]

193. Li, J.M.; Meng, X.G.; Hu, C.W.; Du, J. Adsorption of phenol, p-chlorophenol and p-nitrophenol onto functional chitosan. Bioresour. Technol. 2009, 100, 1168-1173. [CrossRef]

194. Bibi, S.; Yasin, T.; Hassan, S.; Riaz, M.; Nawaz, M. Chitosan/CNTs green nanocomposite membrane: Synthesis, swelling and polyaromatic hydrocarbons removal. Mater. Sci. Eng. C 2015, 46, 359-365. [CrossRef] [PubMed]

195. Filho, C.M.C.; Bueno, P.V.A.; Matsushita, A.F.Y.; Rubira, A.F.; Muniz, E.C.; Durães, L.; Murtinho, D.M.B.; Valente, A.J.M. Synthesis, characterization and sorption studies of aromatic compounds by hydrogels of chitosan blended with $\beta$-cyclodextrin- and PVA-functionalized pectin. RSC Adv. 2018, 8, 14609-14622. [CrossRef]

196. Bahmani, E.; Koushkbaghi, S.; Darabi, M.; ZabihiSahebi, A.; Askari, A.; Irani, M. Fabrication of novel chitosan-g-PNVCL/ZIF-8 composite nanofibers for adsorption of $\mathrm{Cr}(\mathrm{VI}), \mathrm{As}(\mathrm{V})$ and phenol in a single and ternary systems. Carbohydr. Polym. 2019, 224. [CrossRef]

197. Karamipour, A.; Parsi, P.K.; Zahedi, P.; Moosavian, S.M.A. Using $\mathrm{Fe}_{3} \mathrm{O}_{4}$-coated nanofibers based on cellulose acetate/chitosan for adsorption of $\mathrm{Cr}(\mathrm{VI}), \mathrm{Ni}(\mathrm{II})$ and phenol from aqueous solutions. Int. J. Biol. Macromol. 2020, 154, 1132-1139. [CrossRef] [PubMed]

198. Lyu, H.; Hu, K.; Chu, Q.; Su, Z.; Xie, Z. Preparation of ionic liquid mediated molecularly imprinted polymer and specific recognition for bisphenol A from aqueous solution. Microchem. J. 2020, 158. [CrossRef]

199. Ncube, S.; Kunene, P.; Tavengwa, N.T.; Tutu, H.; Richards, H.; Cukrowska, E.; Chimuka, L. Synthesis and characterization of a molecularly imprinted polymer for the isolation of the 16 US-EPA priority polycyclic aromatic hydrocarbons (PAHs) in solution. J. Environ. Manag. 2017, 199, 192-200. [CrossRef]

200. Saad, N.; Chaaban, M.; Patra, D.; Ghanem, A.; El-rassy, H. Molecularly imprinted phenyl-functionalized silica aerogels: Selective adsorbents for methylxanthines and PAHs. Microporous Mesoporous Mater. 2020, 292, 109759. [CrossRef]

201. Azizi, A.; Bottaro, C.S. A critical review of molecularly imprinted polymers for the analysis of organic pollutants in environmental water samples. J. Chromatogr. A 2020, 1614. [CrossRef] [PubMed] 
202. Wei, W.; Liang, R.; Wang, Z.; Qin, W. Hydrophilic molecularly imprinted polymers for selective recognition of polycyclic aromatic hydrocarbons in aqueous media. RSC Adv. 2015, 5, 2659-2662. [CrossRef]

203. Bayramoglu, G.; Arica, M.Y.; Liman, G.; Celikbicak, O.; Salih, B. Removal of bisphenol A from aqueous medium using molecularly surface imprinted microbeads. Chemosphere 2016, 150, 275-284. [CrossRef] [PubMed]

204. Balbino, T.A.C.; Bellato, C.R.; da Silva, A.D.; de Marques Neto, J.O.; de Guimarães, L.M. Magnetic cross-linked chitosan modified with ethylenediamine and $\beta$-cyclodextrin for removal of phenolic compounds. Colloids Surf. A Physicochem. Eng. Asp. 2020, 602. [CrossRef]

205. Heydaripour, J.; Gazi, M.; Oladipo, A.A.; Gulcan, H.O. Porous magnetic resin-g-chitosan beads for adsorptive removal of phenolic compounds. Int. J. Biol. Macromol. 2019, 123, 1125-1131. [CrossRef] [PubMed]

206. Alizadeh, B.; Delnavaz, M.; Shakeri, A. Removal of Cd(II) and phenol using novel cross-linked magnetic EDTA/chitosan/TiO 2 nanocomposite. Carbohydr. Polym. 2018, 181, 675-683. [CrossRef] [PubMed]

207. Rebekah, A.; Bharath, G.; Naushad, M.; Viswanathan, C.; Ponpandian, N. Magnetic graphene/chitosan nanocomposite: A promising nano-adsorbent for the removal of 2-naphthol from aqueous solution and their kinetic studies. Int. J. Biol. Macromol. 2020, 159, 530-538. [CrossRef] [PubMed]

208. Zhou, A.; Chen, W.; Liao, L.; Xie, P.; Zhang, T.C.; Wu, X.; Feng, X. Comparative adsorption of emerging contaminants in water by functional designed magnetic poly(N-isopropylacrylamide)/chitosan hydrogels. Sci. Total Environ. 2019, 671, 377-387. [CrossRef]

209. Nguyen, M.L.; Huang, C.; Juang, R.S. Synergistic biosorption between phenol and nickel(II) from Binary mixtures on chemically and biologically modified chitosan beads. Chem. Eng. J. 2016, 286, 68-75. [CrossRef]

210. Nadavala, S.K.; Swayampakula, K.; Boddu, V.M.; Abburi, K. Biosorption of phenol and o-chlorophenol from aqueous solutions on to chitosan-calcium alginate blended beads. J. Hazard. Mater. 2009, 162, 482-489. [CrossRef]

211. Krupadam, R.J.; Korde, B.A.; Ashokkumar, M.; Kolev, S.D. Novel molecularly imprinted polymeric microspheres for preconcentration and preservation of polycyclic aromatic hydrocarbons from environmental samples. Anal. Bioanal. Chem. 2014, 406, 5313-5321. [CrossRef] [PubMed]

212. Li, H.; Wang, L. Highly selective detection of polycyclic aromatic hydrocarbons using multifunctional magnetic-luminescent molecularly imprinted polymers. ACS Appl. Mater. Interfaces 2013, 5, 10502-10509. [CrossRef] [PubMed]

213. Tiu, B.D.B.; Krupadam, R.J.; Advincula, R.C. Pyrene-imprinted polythiophene sensors for detection of polycyclic aromatic hydrocarbons. Sens. Actuators B Chem. 2016, 228, 693-701. [CrossRef]

214. Saleh, T.A.; Tuzen, M.; Sari, A. Magnetic vermiculite-modified by poly(trimesoyl chloride-melamine) as a sorbent for enhanced removal of bisphenol A. J. Environ. Chem. Eng. 2019, 7. [CrossRef]

215. An, F.; Gao, B.; Feng, X. Adsorption and recognizing ability of molecular imprinted polymer MIP-PEI/SiO2 towards phenol. J. Hazard. Mater. 2008, 157, 286-292. [CrossRef]

216. Liang, W.; Lu, Y.; Li, N.; Li, H.; Zhu, F. Microwave-assisted Synthesis of Magnetic Surface Molecular Imprinted Polymer for Adsorption and Solid Phase Extraction of 4-nitrophenol in wastewater. Microchem. J. 2020, 105316. [CrossRef]

217. Zhao, Z.; Fu, D.; Zhang, B. Novel molecularly imprinted polymer prepared by palygorskite as support for selective adsorption of bisphenol A in aqueous solution. Desalin. Water Treat. 2016, 57, 12433-12442. [CrossRef]

218. Nasreen, S.; Rafique, U.; Ehrman, S.; Ashraf, M.A. Synthesis and characterization of mesoporous silica nanoparticles for environmental remediation of metals, PAHs and phenols. Ekoloji 2018, 27, 1625-1637.

219. Costa, J.A.S.; Sarmento, V.H.V.; Romão, L.P.C.; Paranhos, C.M. Removal of polycyclic aromatic hydrocarbons from aqueous media with polysulfone/MCM-41 mixed matrix membranes. J. Membr. Sci. 2020, 601. [CrossRef]

220. Balati, A.; Shahbazi, A.; Amini, M.M.; Hashemi, S.H.; Jadidi, K. Comparison of the efficiency of mesoporous silicas as absorbents for removing naphthalene from contaminated water. Eur. J. Environ. Sci. 2014, 4, 69-76. [CrossRef]

221. Yuan, P.; Li, X.; Wang, W.; Liu, H.; Yang, H.; Yue, Y.; Bao, X. Tailored design of differently modified mesoporous materials to deeply understand the adsorption mechanism for PAHs. Langmuir 2018. [CrossRef] [PubMed] 
222. Yangui, A.; Abderrabba, M.; Sayari, A. Amine-modified mesoporous silica for quantitative adsorption and release of hydroxytyrosol and other phenolic compounds from olive mill wastewater. J. Taiwan Inst. Chem. Eng. 2017, 70, 111-118. [CrossRef]

223. Zou, D.; Liu, D. Understanding the modifications and applications of highly stable porous frameworks via UiO-66. Mater. Today Chem. 2019, 12, 139-165. [CrossRef]

224. Elsabawy, K.M.; Fallatah, A.M. New advanced approach of ultra-fast synthesis of ultrahigh-BET-surface area crystalline metal-organic-frameworks MOFs. Mater. Lett. 2018, 224, 71-74. [CrossRef]

225. Jiang, D.; Chen, M.; Wang, H.; Zeng, G.; Huang, D.; Cheng, M.; Liu, Y.; Xue, W.; Wang, Z.W. The application of different typological and structural MOFs-based materials for the dyes adsorption. Coord. Chem. Rev. 2019, 380, 471-483. [CrossRef]

226. Mahmoodi, N.M.; Oveisi, M.; Asadi, E. Synthesis of NENU metal-organic framework-graphene oxide nanocomposites and their pollutant removal ability from water using ultrasound. J. Clean. Prod. 2019, 211, 198-212. [CrossRef]

227. Zango, Z.U.; Sambudi, N.S.; Jumbri, K.; Abu Bakar, N.H.H.; Abdullah, N.A.F.; Negim, E.S.M.; Saad, B. Experimental and molecular docking model studies for the adsorption of polycyclic aromatic hydrocarbons onto UiO-66(Zr) and $\mathrm{NH}_{2}-\mathrm{UiO}-66(\mathrm{Zr})$ metal-organic frameworks. Chem. Eng. Sci. 2020, 220, 115608. [CrossRef]

228. Zango, Z.U.; Abu Bakar, N.H.H.; Sambudi, N.S.; Jumbri, K.; Abdullah, N.A.F.; Abdul Kadir, E.; Saad, B. Adsorption of chrysene in aqueous solution onto MIL-88(Fe) and $\mathrm{NH}_{2}-\mathrm{MIL}-88(\mathrm{Fe})$ metal-organic frameworks: Kinetics, isotherms, thermodynamics and docking simulation studies. J. Environ. Chem. Eng. 2019. [CrossRef]

229. Lin, K.A.; Hsieh, Y. Copper-based metal organic framework (MOF), HKUST-1, as an efficient adsorbent to remove p-nitrophenol from water. J. Taiwan Inst. Chem. Eng. 2015, 50, 223-228.

230. Xu, Z.; Wen, Y.; Tian, L.; Li, G. Efficient and selective adsorption of nitroaromatic explosives by Zr-MOF. Inorg. Chem. Commun. 2017, 77, 11-13. [CrossRef]

231. Luo, Z.; Chen, H.; Wu, S.; Yang, C.; Cheng, J. Enhanced removal of bisphenol A from aqueous solution by aluminum-based MOF/sodium alginate-chitosan composite beads. Chemosphere 2019, 237. [CrossRef] [PubMed]

232. Balati, A.; Shahbazi, A.; Amini, M.M.; Hashemi, S.H. Adsorption of polycyclic aromatic hydrocarbons from wastewater by using silica-based organic-inorganic nanohybrid material. J. Water Reuse Desalin. 2015, 5, 50-63. [CrossRef]

233. Costa, J.A.S.; Sarmento, V.H.V.; Romão, L.P.C.; Paranhos, C.M. Synthesis of functionalized mesoporous material from rice husk ash and its application in the removal of the polycyclic aromatic hydrocarbons. Environ. Sci. Pollut. Res. 2019, 26, 25476-25490. [CrossRef] [PubMed]

234. Anbia, M.; Amirmahmoodi, S. Adsorption of phenolic compounds from aqueous solutions using functionalized SBA-15 as a nano-sorbent. Sci. Iran. 2011, 18, 446-452. [CrossRef]

235. Nasreen, S.; Rafique, U.; Ehrman, S.; Ashraf, M.A. Hybrid mesoporous silicates: A distinct aspect to synthesis and application for decontamination of phenols. Saudi J. Biol. Sci. 2019, 26, 1161-1170. [CrossRef]

236. Asgharnia, H.; Nasehinia, H.; Rostami, R.; Rahmani, M.; Mehdinia, S.M. Phenol removal from aqueous solution using silica and activated carbon derived from rice husk. Water Pract. Technol. 2019, 14, 897-907. [CrossRef]

237. Zango, Z.U.; Jumbri, K.; Sambudi, N.S.; Abu Bakar, N.H.H.; Abdullah, N.A.F.; Basheer, C.; Saad, B. Removal of anthracene in water by MIL-88(Fe), $\mathrm{NH}_{2}-\mathrm{MIL}-88(\mathrm{Fe})$, and mixed-MIL-88(Fe) metal-organic frameworks. RCS Adv. 2019, 9, 41490-41501. [CrossRef]

238. Zango, Z.U.; Sambudi, N.S.; Jumbri, K.; Abu Bakar, N.H.H.; Saad, B. Removal of Pyrene from Aqueous Solution Using Fe-based Metal-organic Frameworks. IOP Conf. Ser. Earth Environ. Sci. 2020, 549, 012061. [CrossRef]

239. Zhou, M.; Wu, Y.-n.; Qiao, J.; Zhang, J.; McDonald, A.; Li, G.; Li, F. The removal of bisphenol A from aqueous solutions by MIL-53(Al) and mesostructured MIL-53(Al). J. Colloid Interface Sci. 2013, 405, 157-163. [CrossRef]

240. Tan, Y.; Sun, Z.; Meng, H.; Han, Y.; Wu, J.; Xu, J.; Xu, Y.; Zhang, X. A new MOFs/polymer hybrid membrane: MIL-68(Al)/PVDF, fabrication and application in high-efficient removal of p-nitrophenol and methylene blue. Sep. Purif. Technol. 2019, 215, 217-226. [CrossRef] 
241. Han, T.; Li, C.; Guo, X.; Huang, H.; Liu, D.; Zhong, C. In-situ synthesis of $\mathrm{SiO}_{2} @ \mathrm{MOF}$ composites for high-efficiency removal of aniline from aqueous solution. Appl. Surf. Sci. 2016, 390, 506-512. [CrossRef]

242. Abazari, R.; Salehi, G.; Mahjoub, A.R. Ultrasound-assisted preparation of a nanostructured zinc(II) amine pillar metal-organic framework as a potential sorbent for 2,4-dichlorophenol adsorption from aqueous solution. Ultrason. Sonochem. 2018, 46, 59-67. [CrossRef] [PubMed]

243. Abazari, R.; Mahjoub, A.R. Ultrasound-assisted synthesis of Zinc(II)-based metal organic framework nanoparticles in the presence of modulator for adsorption enhancement of 2,4-dichlorophenol and amoxicillin. Ultrason. Sonochem. 2018, 42, 577-584. [CrossRef] [PubMed]

244. Han, T.; Xiao, Y.; Tong, M.; Huang, H.; Liu, D.; Wang, L.; Zhong, C. Synthesis of CNT@MIL-68(Al) composites with improved adsorption capacity for phenol in aqueous solution. Chem. Eng. J. 2015, 275, 134-141. [CrossRef]

245. Jung, B.K.; Hasan, Z.; Jhung, S.H. Adsorptive removal of 2,4-dichlorophenoxyacetic acid (2,4-D) from water with a metal-organic framework. Chem. Eng. J. 2013, 234, 99-105. [CrossRef]

246. Guo, H.; Niu, B.; Wu, X.; Zhang, Y.; Ying, S. Effective removal of 2,4,6-trinitrophenol over hexagonal metal-organic framework $\mathrm{NH}_{2}$-MIL-88B(Fe). Appl. Organomet. Chem. 2018, 33, e4580. [CrossRef]

247. Giraldo, L.; Bastidas-Barranco, M.; Húmpola, P.; Moreno-Piraján, J.C. Design, synthesis and characterization of MOF-199 and ZIF-8: Applications in the adsorption of phenols derivatives in aqueous solution. Eur. J. Chem. 2017, 8, 293-304. [CrossRef]

248. Ahsan, M.A.; Jabbari, V.; Islam, M.T.; Turley, R.S.; Dominguez, N.; Kim, H.; Castro, E.; Hernandez-Viezcas, J.A.; Curry, M.L.; Lopez, J.; et al. Sustainable synthesis and remarkable adsorption capacity of MOF/graphene oxide and $\mathrm{MOF} / \mathrm{CNT}$ based hybrid nanocomposites for the removal of Bisphenol A from water. Sci. Total Environ. 2019, 673, 306-317. [CrossRef]

249. Zhang, R.; Wang, L.; Han, J.; Wu, J.; Li, C.; Ni, L.; Wang, Y. Improving laccase activity and stability by HKUST-1 with cofactor via one-pot encapsulation and its application for degradation of bisphenol A. J. Hazard. Mater. 2020, 383. [CrossRef]

250. Kamali, M.; Persson, K.M.; Costa, M.E.; Capela, I. Sustainability criteria for assessing nanotechnology applicability in industrial wastewater treatment: Current status and future outlook. Environ. Int. 2019, 125, 261-276. [CrossRef]

251. El-Naas, M.H.; Surkatti, R.; Al-Zuhair, S. Petroleum refinery wastewater treatment: A pilot scale study. J. Water Process Eng. 2016, 14, 71-76. [CrossRef]

252. Kalmykova, Y.; Moona, N.; Strömvall, A.M.; Björklund, K. Sorption and degradation of petroleum hydrocarbons, polycyclic aromatic hydrocarbons, alkylphenols, bisphenol A and phthalates in landfill leachate using sand, activated carbon and peat filters. Water Res. 2014, 56, 246-257. [CrossRef] [PubMed]

253. Frascari, D.; Bacca, A.E.M.; Zama, F.; Bertin, L.; Fava, F.; Pinelli, D. Olive mill wastewater valorisation through phenolic compounds adsorption in a continuous flow column. Chem. Eng. J. 2016, 283, 293-303. [CrossRef]

Publisher's Note: MDPI stays neutral with regard to jurisdictional claims in published maps and institutional affiliations.

(C) 2020 by the authors. Licensee MDPI, Basel, Switzerland. This article is an open access article distributed under the terms and conditions of the Creative Commons Attribution (CC BY) license (http://creativecommons.org/licenses/by/4.0/). 